\title{
Article \\ Geoarchaeology: Where Geosciences Meet the Humanities to Reconstruct Past Human-Environment Interactions. An Application to the Coastal Areas of the Largest Mediterranean Islands
}

\author{
Matthieu Ghilardi (1)
}

check for

updates

Citation: Ghilardi, M

Geoarchaeology: Where Geosciences

Meet the Humanities to Reconstruct

Past Human-Environment

Interactions. An Application to the

Coastal Areas of the Largest

Mediterranean Islands. Appl. Sci.

2021, 11, 4480. https://doi.org/

10.3390/app11104480

Academic Editor: Adriano Ribolini

Received: 29 March 2021

Accepted: 11 May 2021

Published: 14 May 2021

Publisher's Note: MDPI stays neutral with regard to jurisdictional claims in published maps and institutional affiliations.

Copyright: (C) 2021 by the author. Licensee MDPI, Basel, Switzerland. This article is an open access article distributed under the terms and conditions of the Creative Commons Attribution (CC BY) license (https:// creativecommons.org/licenses/by/ $4.0 /)$.
(AMU)-IRD-Collège de France-INRAE, CEREGE UMR 7330 CNRS-Aix-Marseille University, CEDEX 04, Europôle de 1'Arbois BP 80, 13545 Aix-en-Provence, France; ghilardi@cerege.fr

\begin{abstract}
The study of past Human-Environment interactions has long been seen at a very local scale, that of sites of human occupation. Geoarchaeology differs from the traditional concepts of Environmental Archaeology and Landscape Archaeology in this respect since it adopts a different spatial resolution based on the development of multidisciplinary research at the scale of geographical, geological or geomorphological features. In this paper, we aim to contribute to the definition of coastal geoarchaeology where environmental holistic studies can be developed, thus integrating both continental and marine dynamics. A specific application is realized here for the largest Mediterranean islands where heterogeneity can be observed in research over the last decades. For this reason, we divide the Mediterranean Basin into four areas in order to review the main works conducted. In general, investigating coastal environments represents an exciting opportunity to reconstruct past landscapes and to evidence the long-term history of human occupation and land use by employing a wide range of proxies. We focus in particular on the coastal wetlands of Corsica, where a large number of lagoons have been cored since the early 2010s. Multiproxy laboratory analyses reveal a history of the complex relationships between past human societies and their environments which is complementary to existing archaeological studies.
\end{abstract}

Keywords: geoarchaeology; geosciences; human sciences; multidisciplinary; Mediterranean; islands; palaeoenvironments

\section{Introduction}

Since the United Nations conference of Rio de Janeiro (Brazil) in 1992, there has been a growing interest in the study of the direct consequences of human activities in terms of development and environmental impacts [1] on the climate in particular, and human responsibility is today recognized as a contributor to Global Warming. Other indirect consequences of anthropogenic actions have also been evoked, notably an increasingly rapid oceanic sea level rise since the Industrial Revolution. Over the last years, a sense of emergency has driven a need to highlight the deleterious effects that anthropogenic actions are having on flora and fauna diversity and composition, and which are threatening the Earth with a sixth mass extinction [2,3]. Studying both present-day and future relationships between humans and their nearby environments is a key issue for politicians and scientists alike due to the sizeable economic interests involved [4]. If this short-intermediate-term view of the interactions is based more on a predictive approach, largely derived from modelling of already published material, both the regressive and empirical views have been given less priority despite the key role they play in the evaluation of how human actions impact their environment over the long-term history.

The Mediterranean Sea testifies to a long-term history of human occupation and is probably one of the best-documented areas in the world from both archaeological and 
palaeoenvironmental perspectives. Surprisingly, however, the Mediterranean islands and archipelagos are less documented than the continental margins, despite the fact that they probably served as relays for ancient civilizations between the north/south and east/west sides of the so-called Mare Nostrum [5].

The first aim of this paper is to contribute to defining geoarchaeology and to differentiate this concept from other multidisciplinary approaches that aim at reconstructing the Human-Environment interactions for the Holocene notably.

Secondly, we deliver a pertinent overview of the coastal geoarchaeological research that has been conducted on the four main insular complexes of the Mediterranean Sea: Cyprus-Levant, Aegean Basin, Central (Sicily-Malta-Ionian and Adriatic islands) and Western (Corsica-Sardinia-Balearic archipelago).

Thirdly, research conducted more specifically on Corsican coastal wetlands will be detailed and will be proposed as a reference for forthcoming studies that will attempt to differentiate between the impacts of anthropogenic actions and natural processes on the evolution of landscape within an insular context. Both published material and new data are incorporated for presentation, and we detail the methods employed for geoarchaeological purposes, and we present some main highlights of the research.

\section{Defining the Concept of Geoarchaeology}

Archaeological sites, in particular, provide precious if not unique windows onto past relationships between human populations and their nearby environments. After long being dedicated primarily to the study of archaeological remains, a major turning point occurred at the end of the 1960s when the School of New Archaeology began to see sites of human occupation as having multidisciplinary scientific interest [6,7]. Indeed, specialists began to adopt geosciences-based approaches that enabled the reconstruction of environmental history at the same time as specialists in the Human Sciences were focusing on the social interpretation of human artifacts buried under the sediments. From then on, the development of Environmental Archaeology was spectacular and often focused on the local, within-site (in situ) scale [7]. The concept of geoarchaeology differs from Environmental Archaeology and Landscape Archaeology in the sense that the study scale it exceeds that of human occupation to encompass the Geo- as in geomorphology, geology or geography. Practically speaking, this means that it is the reconstruction of Human-Environment interactions that must be enlarged, rather than any physically defined boundaries [8]. This is supported by the fact that archaeological sites, or vestiges, can be integrated into one geographical, geomorphological or geological landscape unit where human networks have been built for millennia and have thus enabled the territory organization. For example, river systems use to be the most favoured geomorphological framework and led the development of fluvial geoarchaeology [9-12]. Alluvial sediments then acquired particular importance for reconstructing the environment at a catchment scale: times of erosion, transport and accumulation were separated and studied under the spectrum of human disturbance and natural forcing on slope systems, from source to sink, mainly from the beginning of Neolithization.

Another branch of geoarchaeology is dedicated to coastal environments. This is a growing field of multidisciplinary research that aims at reconstructing the palaeogeography of river deltas, estuaries and wetlands (mainly lagoons, marshes and ponds) together with the adaptation of human societies to constantly changing shoreline positions since at least the mid-Holocene [13]. This date is of importance as it corresponds to the beginning of the post-glacial slowdown in sea level rise when a mechanism of coastal progradation was initiated $[14,15]$, thus provoking the formation of wetlands parallel to the shoreline. Coastal wetlands form a receptacle for sediments carried away by both continental and marine delivery sources, and as a result, they provide a unique opportunity to precisely reconstruct a holistic Holocene landscape evolution. From a long-term historical perspective, these water resources have always been important places for human settlements, starting from Mesolithic times and continuing to the present day: environmental and ecological interests 
are numerous, and reconstructing the palaeoenvironments of coastal wetlands can also help to reshape and better define territories under human influence.

\section{Coastal Geoarchaeology of the Largest Mediterranean Islands: A Brief Overview and Main Highlights}

There are today approximately 10,000 islands across the Mediterranean, of which $250-300$ are inhabited $[16,17]$ by a total of ca. 10 million people. From a long-term historical perspective, these "isolated" pieces of land acted as vibrant places in the settlement process of the Mediterranean and were an important stage for both the exploitation of natural resources (stone tools, etc.) and for the spread of agriculture beginning in the early stages of Neolithization. Coastal areas were the gateways for seafarers to discover, colonize and exploit these islands. The development of agriculture was first initiated in Cyprus (Levant), and it then crossed the whole Mediterranean with a possible spread via the islands. Later, the Bronze Age and Antiquity mark a major turning point in the development of Mediterranean civilizations, when these emerged pieces of land became important centres of exchanges of goods, thanks to their geostrategic position at the crossroads between Africa, Europe and Asia. Below, we delineate four main geographical zones, from the east to the west of the Mediterranean and provide a non-exhaustive list of the main coastal geoarchaeological research conducted over the last decades.

\subsection{Cyprus (Levant)}

The island of Cyprus is located a short distance from the coastline of modern Anatolia $(70 \mathrm{~km})$ and at a greater distance from the Levant mainland $(100 \mathrm{~km})$. The third-largest Mediterranean island is well known for harbouring the earliest traces of Neolithization across the Mediterranean, dating back to at least the first half of the 9th millennium BCE $[18,19]$. Since the 1970s, numerous sites, mostly situated a short distance from the shore in the lower river valleys on the southern coast of Cyprus, have been identified and excavated to better understand the environmental conditions during settlement by the first farmers. The latter probably came from various places around the Levant rather than from Anatolia alone [18]. Archaeobotanical data (plant remains, wood, charcoals, seeds, etc.) collected at the within-site scale $[20,21]$ have helped to (i) reconstruct to a large degree the vegetation cover in the close vicinity of the investigated sites (some of which date from the aceramic Neolithic culture also called Prepottery Neolithic B) and (ii), to enable the identification of the different Neolithic founder crops, including einkorn, emmer, hulled barley, lentil and pea which were the most commonly occurring domestic species during the island's aceramic Neolithic period. These valuable papers show a rather limited spatial interpretation due to an important taphonomic bias, and they deal more with the concepts of Environmental Archaeology or Landscape Archaeology. In their review of the reconstruction of palaeoenvironments of Cyprus, Butzer and Harris [22] underline the paucity of regional studies. Almost no work has attempted to precisely reconstruct the vegetation configuration at a larger scale, neither before the introduction of the Neolithic culture nor during the entire Neolithic culture. Derived palaeoecological data at a within-site study cannot fully reflect a complete view of the past landscape, and therefore cannot be considered satisfactory. In addition, the lack of a natural reservoir of water, which would include all types of wetlands, is one of the main reasons evoked by Butzer and Harris to explain the small number of palaeoenvironmental studies conducted until the late 2000s [22]. Further to palaeolandscape configuration, precious information about a pre-colonization of the island by seafarers is provided in the major studies led by A. Simmons and his team, who examine the question of the dwarf hippo, presumably driven to extinction by humans [23-25]. The excavation conducted on the site of AkrotiriAetokremnos (south central coast of Cyprus) during the 1980s and 1990s provided a great number of ${ }^{14} \mathrm{C}$ dating results and osteological investigations (traces of cut marks identified on bones), which revealed the coexistence, probably for only a short period of time, of human groups and dwarf hippos. This period dates slightly before the emergence of the early aceramic Neolithic culture; the mean date of ca. 9700 cal. BCE was obtained for 
the extinction of this mammal. Seasonal visits of seafarers from the nearby mainlands (Anatolia and Levant) probably began ca. 10,000 BCE [18,26,27], but the reasons behind these frequent visits are still under debate (one possible suggestion is that they came to exploit mineral resource). In short, a large part of the studies conducted close to the coast of Cyprus since the 1970s mainly focused on the beginning of the Holocene and have attempted to identify the local environmental conditions related to the introduction of agriculture during the Late Pleistocene when humans already frequented the island for its natural resources (chert), which they used to make stone tools. However, the geographical scale of these studies did not enable the full reconstruction of the interactions between humans and their environments.

With the exception of that research dedicated to Environmental Archaeology as it relates to local landscape conditions of the hunter/gatherer to farmer transition, geoarchaeological investigations have mainly been restricted to the coastal wetlands located on the southern coast of Cyprus. Since the 2010s, the Middle to Recent Holocene palaeogeography of the lagoons has been reconstructed and is now largely based on the study of cores using palaeoecological proxies, including pollen studies. One of the aims of these analyses has been to precisely reconstruct the coastal landscape configuration of present-day lagoons during the Bronze Age and Antiquity. For the latter periods, several ancient harbours (previously connected to the sea) have been identified and replaced within their original context of use [28]. Lagoons are generally the remnant evidence of a former marine incursion and are of great interest for the reconstruction of vegetation composition, based on the identification of well-preserved pollen grains and spores in these calm depositional environments [29]. Both palaeoecological evidence and archaeological interpretations help to better evaluate the resilience of past human societies to natural forcings, such as abrupt climate changes $[29,30]$. Nonetheless, multidisciplinary discussions between scientific communities on this last point are infrequent, which impoverishes interpretations based only on geosciences data.

\subsection{The Aegean Basin}

Over the last decades, research dealing with coastal geoarchaeology has been a growing sector within the tectonically very active Aegean Basin and has mainly focused on the morphological impact of the last post-glacial sea-level rise. Particular attention has been paid to reconstructing past sea-level positions and the effects of regional/local tectonics, based on the cross-contribution of both archaeological evidence and of geomorphological markers (uplifted or submerged notches and slabs of beachrocks). Important aspects of these studies include geomorphological consequences and human implications. Most of the relevant research has been conducted in western Crete [31-33], in Rhodes [34], and in the Cyclades at Delos-Mykonos-Rhenea [35,36], Keos [37], Andros [38] and at Paros [39].

A key symbol of this facet of coastal geoarchaeology in a very active seismic context is the morphological impacts of what is known as the Early Byzantine Paroxysm [31] and its consequences on the coastal sites of human occupation of western and south western Crete. This 8.5+ magnitude earthquake occurred in 365 CE [40] and provoked the violent uplifting of western Crete. The maximum amplitude of ca. $9 \mathrm{~m}$ (Figure 1a) has been observed on the western coast of the island [40,41], decreasing in intensity eastwards as far as the Gulf of Tymbaki (Figure 1a) in South Central Crete. Morphological evidence of this coseismic event remains visible at different elevations through the presence of a bioerosional notch situated above the present-day sea level [41]. This uniform geomorphological unit is the common feature of many archaeological sites dating from Minoan times to Antiquity, which are located all along the southwestern coast of the island. As a direct consequence, the ancient coastal harbour of Falarsana (western Crete) is today situated inland at an elevation of ca. $6.6 \mathrm{~m}$ amsl [32] (Figure 1b). Further to the east, in the area of Ancient Lyssos (Figure 1a,c), the coseismic bioerosional notch is visible at an elevation of ca. $7 \mathrm{~m}$ above the present-day sea level and uplifted the harbour basin to a similar elevation. Still further east, at Sougia, the notch can be seen at ca. 6.50 to $7 \mathrm{~m}$ amsl (Figure 1d), and the ancient harbour of 
Sougia is now situated inland. Finally, at Loutro, the notch is readily observable at an elevation of ca. $4.5 \mathrm{~m}$ amsl (Figure 1e). Here, coastal geoarchaeology is related to the societal consequences of this abrupt environmental change at the end of Roman times and the beginning of the Byzantine period.

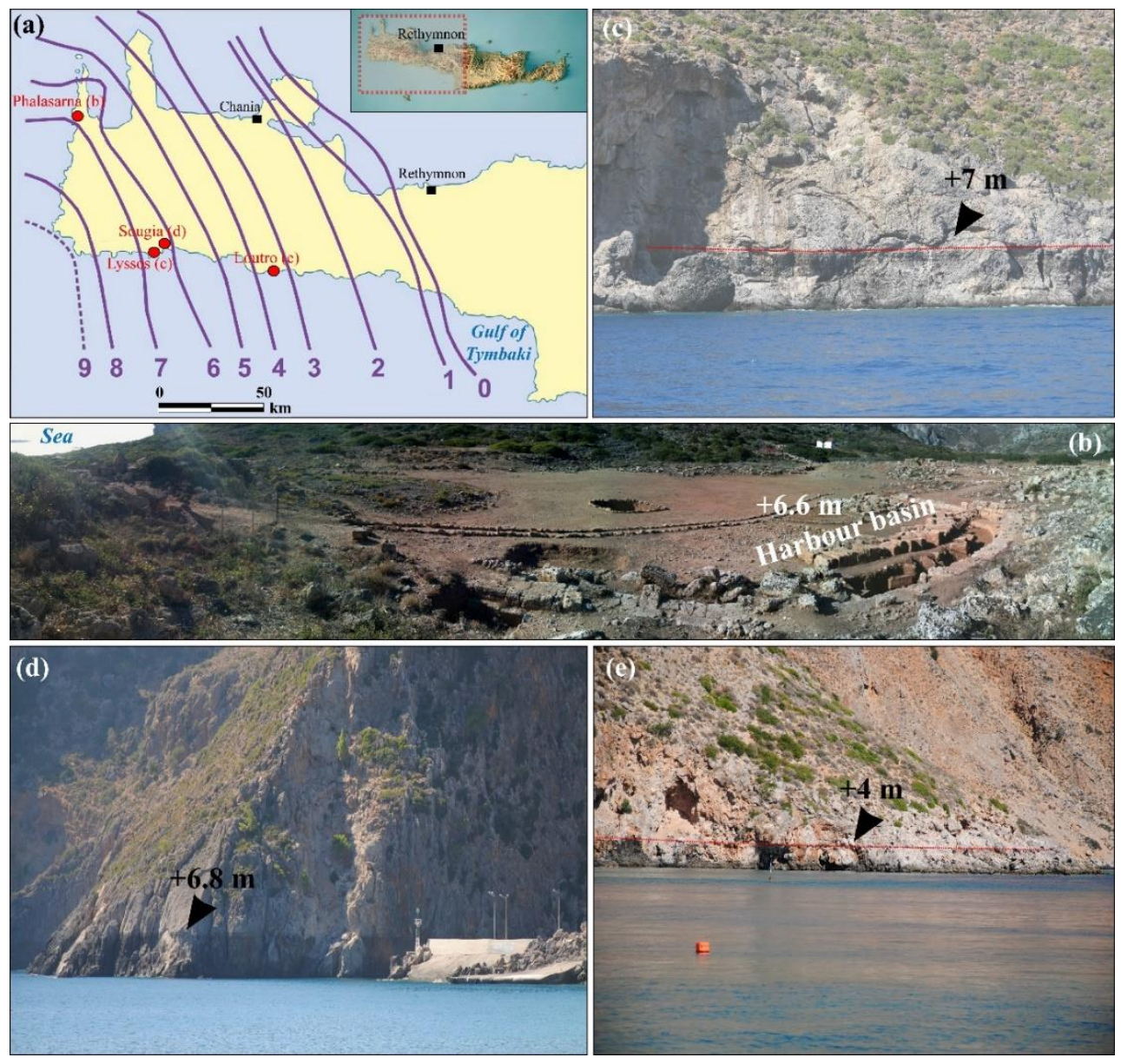

Figure 1. Different views of the $365 \mathrm{CE}$ coseismic bioerosional notch. This notch is related to a regional uplift of the westernmost part of Crete and can be observed at different elevations above present-day sea level (a). Purple lines in (a) are isobases marking the uplift. Archaeological implications are important since various sites (mostly harbour basins) were landlocked: at Phalarsana (b), Lyssos (c), Sougia (d) and Loutro (e).

A second aspect of the coastal geoarchaeological studies conducted on the islands of the Aegean Sea concerns the reconstruction of the land- and seascape configuration, taking into account both the evaluation of shoreline displacement and the reconstruction of vegetation composition under human and climatic forcings. Investigating Holocene sediment accumulation of coastal wetlands is useful for reconstructing whole landscape configurations and then integrating sites of human occupation at a regional scale of changing environments. This type of work mainly consists of drilling boreholes in coastal wetlands, usually in lagoons that formed over the last six millennia. Investigations conducted on the islands of Thassos [42], Samos [43], Limnos [44], Skyros [45] and Paros [46] comprise some of the most relevant work undertaken over the last two decades.

A good example of this enlarged approach to Human-Environment interactions is obtained on the island of Euboea (west central Aegean), on the southern Euboean Gulf, where a great number of major ancient sites (among which are Avlida, Eretria and Amarynthos) have been identified within a deltaic context or in former marine embayments, later silted up by a mixture of continental and marine deposits [47]. Sanctuaries dedicated to Artemis, 
the goddess of the hunt and of swamps, have been identified in many places along the coastline of the Southern Euboean Gulf and clearly indicate a common landscape configuration where coastal swamps probably played a determining role in the building of these sanctuaries, during both the Classical and the Hellenistic periods. From an archaeological perspective, this specific landscape configuration has only rarely been taken into consideration to precisely locate some of the temples associated with the goddess. Furthermore, little attention had been paid to reconstructing the coastal landscape configuration until recent studies [48,49]. Most of the deltaic environments where sanctuaries of Artemis were first mentioned by ancient writers and later rediscovered (sometimes only very recently [50]) have been investigated in terms of environmental history using coring. The main results highlight a second major phase of deltaic progradation (the first phase is identified at the end of the Late Neolithic to Early Bronze Age) along the southern part of the Euboean Gulf, starting around the 9 th Century BCE. As a consequence, the shoreline gradually advanced and created extensive areas of land due to the thick deposition of alluvial material. Another direct morphological consequence is the appearance of lagoons and coastal ponds that formed from the early 1st millennium BCE to Late Roman times. The palaeoenvironmental data, based on borehole chronostratigraphy, is of great importance from a geoarchaeological perspective and can deliver valuable information about general coastal landscape configuration during a period of flourishing human activities. In a major finding, the exact location of the sanctuary of Artemis at Amarynthos was confirmed thanks in part to the palaeoenvironmental results obtained [48] before its unambiguous discovery [50]. The case study of the island of Euboea and the presence of associated sanctuaries to Artemis highlights obvious Human-Environment interactions, both in a coastal landscape and in a regional context, and underlines another aspect of coastal geoarchaeology. In doing so, coastal wetlands acquire high multidisciplinary interest.

\subsection{Central Mediterranean (Sicily-Malta-Ionian and Adriatic Seas)}

Despite Sicily being the largest Mediterranean island, geoarchaeological research along its shoreline is scarce and most existing studies are more in phase with the concept of Landscape Archaeology, where a within-site scale has been adopted. However, we can cite the valuable work conducted on the eastern and western coasts of the island, south of Syracuse [51], and in Marsala Sound [52], respectively. Both studies aimed at investigating lagoonal/brackish sediments in order to reconstruct shoreline shifting and past sea-level changes. Nonetheless, the archaeological implications were limited, and palaeoecological proxies were not systemically included. The potential for developing coastal geoarchaeology along the Sicilian coast is important because the archaeological context is rich [53] and numerous coastal wetlands have been identified, mainly situated within a fluvio-deltaic context and at a short distance from major ancient sites [54]. Moreover, the active tectonics of the island have provoked local subsidence and even the submersion of well-dated archaeological structures [54]. In the future, one component of Sicilian coastal geoarchaeology should be dedicated to reconstructing the past sea- and landscapes in order to obtain long-term estimates of subsidence rates, which could then be integrated into present-day coastal management scenarios.

The Maltese Archipelago (Malta, Gozo and Comino islands) is situated between Sicily and Tunisia and has a long-term history of human occupation. Over the last decade, specific interest has been given to the reconstruction of past Human-Environment interactions in Malta $\left(246 \mathrm{~km}^{2}\right)$. This island records vestiges of a series of former fluvial valleys (incised during previous glacial periods) that subsequently developed into rias (inundated valleys during the postglacial maximum marine ingression) and finally into fluvio-deltaic plains in the Middle Holocene [55]. These rias are an almost unique geomorphological feature at the scale of the Mediterranean islands and are frequently encountered on Malta. The Mid- to Late Holocene alluvial deposition in these former marine corridors has been investigated to reconstruct both shoreline displacements and, more generally, landscape configuration, including vegetation history. Similar to the research undertaken in the Aegean Basin, the 
development of coastal geoarchaeology on Malta has helped to better understand human impacts on sediment dynamics since the beginning of anthropization at a catchment scale. Palaeoecological proxies, such as pollen identification and fire signal study, have been combined in order to evaluate the first signs of agriculture and its impacts in terms of soil erosion and related alluvial activity (deltaic progradation). Reconstructing land-use practices has revealed the first signs of agriculture approximately 7300 years ago, which is broadly consistent with the earliest archaeological traces observed in the catchment and its surroundings [55].

On the Ionian coast of the Greek mainland, several islands (Corfu, Levkas, Ithaka, Cephalonia, Meganisi and Zante) have been investigated in order to reconstruct both past sea-level changes and palaeoseismic events $[56,57]$. Unfortunately, these studies are of limited archaeological interest, despite the islands having well-documented archaeological backgrounds. The most relevant coastal geoarchaeological research exists for the island of Corfu (ca. $590 \mathrm{~km}^{2}$ ) and was of major multidisciplinary interest in dating the transition from Mesolithic hunter-gatherers to the development of Neolithic culture. In the NW part of the island, the site of Sidari is situated on a coastal cliff where, due to marine erosion, a Holocene terrestrial sedimentary sequence was revealed. The site shows an alternation between fluvial accumulation layers and soil horizons which were later studied for palaeoenvironmental reconstruction [58] and accurate dating. In parallel, the archaeological context was well defined at a local scale, and the first signs of an Early Neolithic occupation were revealed due to systematic excavations and the characterisation of the uncovered material. A robust chronostratigraphy was obtained for the stratigraphic profile, based on performing approximately 20 radiocarbon dating analyses; this helped to date with more precision the arrival of Neolithic communities on Corfu in a context of much lower sea level than today. Micromorphology helped to better understand palaeosoil formation, and the emergence of the Neolithic culture has been accurately dated to around 6450-6200 cal. BCE, while the Mesolithic period spans the period between 7100 and $6600 \mathrm{cal}$. BCE. In summary, the coastal environments (cliff affected by erosion) of Corfu have provided major palaeoenvironmental information necessary for better dating the transition from Mesolithic to Neolithic across the Mediterranean. The multidisciplinary research conducted over the last decades at Sidari, Corfu, represents another aspect of coastal geoarchaeology dealing with stratigraphy as revealed by the marine erosion of cliffs.

The eastern part of the Adriatic Sea records a high number of rocky islands (mostly situated a short distance from the shoreline of mainland Croatia) where Holocene coastal sediment accumulation occurs in some places only. Until now, few of these lagoons had been investigated for palaeoenvironmental reconstruction purposes. Some of the lagoons that formed on Pag Island $\left(305 \mathrm{~km}^{2}\right)$ were investigated in order to reconstruct past sea-level changes and to identify sedimentary signatures of past seismic events [59]. Archaeological indicators, together with sediment chronostratigraphy from cores, were then used to accurately date the formation of a region-wide submerged marine notch situated 45 to $115 \mathrm{~cm}$ below present-day sea level. An age of 1000-1200 cal. CE was obtained based on a series of radiocarbon dating.

\subsection{Western Mediterranean (Balearic Islands and Sardinia-Corsica)}

The Western Mediterranean reports the most in-depth research dedicated to coastal geoarchaeology, even though the islands situated on the northern coast of Africa (mainly located a short distance from Tunisia) and the Tuscan archipelago remain little studied. One reason for such developed multidisciplinary research can be explained by the presence on the largest islands of a great number of coastal wetlands, which have been investigated simultaneously by both archaeologists and geoscientists.

Based on archaeological evidence, the Balearic Islands were colonized around the mid-3rd millennium BCE [60-62] by human groups probably originating from what is today Catalunya [63]. No evidence of Neolithic culture has been recognized in the Gymnesic nor in the Pythusian islands, creating a unique situation from a geoarchaeological 
perspective for the entire Mediterranean. It is also noteworthy that the Balearic Islands are one of the most widely dated regions in Europe, totalling about 750 radiocarbon dates for 118 sites [64]. Thus, this area of the Mediterranean can be said to provide a great opportunity to reconstruct, within a precisely dated archaeological framework, the landscape configuration prior to human occupation and to compare the situation during the period of the anthropization of the archipelago. The numerous lagoons and coastal ponds located on Majorca, Minorca, Ibiza and Formentera, offer a unique opportunity to reconstruct and compare, from island to island, past Human-Environment interactions during the late Holocene. These comparisons are based on the use of palaeoecological multiproxies (in particular, pollen identification) derived from borehole studies. In addition, the pre-anthropic environments have also been reconstructed (representing the lowermost part of the sedimentary sequence) and help to clearly reveal climate control on vegetation composition, as well as to evaluate the later effects of human disturbance on these environments. Thus, geoarchaeology is a convincing approach to evaluate, at a regional scale and from a short- to long-term perspective, present-day questions related to the origins of global environmental changes caused by both natural and anthropogenic factors. In their concise analysis of the vegetation history of the Balearic Islands, F. Burjachs et al. [61] not only focused on the main changes in terms of vegetation cover caused by either climatic forcing (for the pre- anthropic period) or by a mixture of climatic and anthropogenic origins (since the mid-3rd mill. BCE), but the authors also evaluated the evolution of land-use and the development of agricultural practices as indicators of changes relating to human occupation dynamics. To summarize, geoarchaeological research conducted in the coastal wetlands of the Balearic Islands is relevant for the better understanding of complex environmental adaptations of landscapes to both natural and anthropogenic forcings from short- to long-term perspectives, and these studies can also be of great help in comparing pre- and post-industrial situations. Finally, preservation of coastal wetlands in the context of rapid urbanization in the Balearic Islands is crucial, both for present-day ecological studies and in the context of palaeoenvironmental/geoarchaeological interests.

Sardinia and Corsica are thought to be highly connected from an archaeological point of view as they formed a single island during the Last Glacial Maximum [16]. One aspect of geoarchaeological research concerns the appearance and spread of agriculture, possibly from Sardinia to Corsica at the beginning of the Cardial Neolithic culture. Over the last decade, coastal wetlands (lagoons, ponds and lakes) of Sardinia, the second-largest Mediterranean island, have been investigated to reconstruct a complete history of the landscape changes, from both palaeogeographical and palaeoecological perspectives [65-67]. On this point, archaeobotanical information is scarce at a within-site scale, and the few sites dated from Early Neolithic times only hint at traces of agriculture. One of the challenges facing coastal geoarchaeology in Sardinia-Corsica is to elucidate major questions related to the spread of agriculture between the two islands (across the Bonifacio Strait), where archaeology reveals limited information: the aim of the palaeoenvironmentalist is thus to improve this knowledge and provide precious information for archaeologists, prehistorians and anthropologists. Most of Sardinia's coastal wetlands formed due to the post-glacial sea-level rise slowdown and the associated deltaic progradation. Brackish sediments contributed to the good preservation of pollen and fossil Non-Pollen Palynomorph (NPP; [68]), which help to evaluate land use, cereal cultivation and pastoralism in particular. Holocene landscape reconstruction of the deltaic plains of La Posada (north-east Sardinia) and Tirso (west central Sardinia), and the coastal brackish lake of Sa Curcurica (NE Sardinia) have helped to evaluate shoreline displacements and provide, in addition, the first convincing sign of anthropization in a coastal environment detected using pollen investigation. Evidence for Cerealia-type cultivation is recorded in most of the sites during Early Neolithic times and possibly at the beginning of the Cardial culture, dated ca. $5500 \mathrm{cal}$. BCE, at the site of La Posada [66]. At the Tirso and Sa Curcurica sites, clear evidence for agriculture is dated later. 
Concerning the Corsican shoreline, this region remained little investigated in palaeoecological terms until the 2010s, and the only studies conducted by M. Reille in the 1980s showed no robust chronostratigraphy [69], which thus strongly limits the archaeological implications. It was only very recently that cores revealing robust chronostratigraphy $[70,71]$ were drilled in coastal wetlands of the island. Pollen investigations could then be discussed in terms of human activities at a high-resolution level. A great number of sites in the southernmost part of Corsica date from Mesolithic to Early Neolithic times [72]. However, few details are known regarding Human-Environment interactions. At Piantarella (situated $5 \mathrm{~km} \mathrm{SE}$ of the modern town of Bonifacio), a lagoon that formed approximately 7700 years ago revealed pollen that was well preserved for the whole Neolithic sequence [71]. Currently, no site dated from this last period has been identified around the wetland. The first signs of agriculture are evidenced at ca. $5450 \mathrm{cal}$. BCE with the development of pastoralism (identification of NPPs) within a deforestation context (a strong decrease in Erica taxon that formed the original coastal vegetation of the island), and approximately one century later, cereal cultivation can be observed (Cerealia-type). The palaeoenvironmental results clearly evidence human occupation in an area where archaeological information is lacking. Coastal geoarchaeology in the case of Sardinia-Corsica helps to better define land-use practices related to the first stages of the Early Neolithic period and contributes to a better understanding of the spread of agriculture across the Mediterranean via the islands.

\section{Materials and Methods Used to Reconstruct Past Human-Environment Interactions within the Context of Coastal Wetlands of Corsica}

Corsica is the fourth largest Mediterranean island and counts approximately two hundred coastal wetlands (Figure 2a,b), which mainly formed during the last six millennia due to the post-glacial sea level rise slowdown $[73,74]$. Some of these formed due to the deltaic progradation of the main rivers of the island, while others were the result of a combination of particular coastal configuration and Holocene spatial redistribution of sediments by the sea parallel to the palaeoshore (isolation of marine to brackish waters behind a natural barrier). Being subaqueous, wetland sediments do not form soils and do not directly support archaeological sites, although they may incorporate archaeological materials [6]. Their importance lies more in their centrality for palaeoenvironmental reconstructions and in the fact that they are influenced by both marine and terrestrial dynamics of sedimentation, thus necessitating a multiproxy approach. The range of techniques that can potentially be applied to geoarchaeological goals is derived from related disciplines. However, the purpose of geoarchaeology is to select those procedures that will yield the results that are the most adapted to the accurate evaluation of a particular palaeoenvironmental context [7] within the constraints of available financial and human resources.

Field surveys, coring campaigns and laboratory analyses must be discussed as a whole by geoarchaeological teams to reveal how they relate to cross-disciplinary scientific interests, rather than simply determining their usefulness for reconstructing environments exclusively for archaeological purposes. A wide range of specialists is involved in studying sediments to answer questions that may be related to past landscape dynamics and complex Human-Environment interactions.

\subsection{Defining a Precise Geomorphological Map Based on Field Surveys}

The first step of a multidisciplinary approach that aims to define past landscape configuration in the vicinity of one or several site(s) installed around a coastal wetland is to establish a precise geomorphological map. Firstly, Holocene landforms must be distinguished from Pre-Holocene ones. Clear differences must also be made between terrestrial and coastal features. An essential tool for the creation of a georeferenced geomorphological map, superimposed upon the archaeological layers, is the Geographic Information System (GIS). It is noteworthy that the archaeological context surrounding the wetlands in Corsica is documented thanks to previous regional surveys and excavations. All data have been georeferenced by the local archaeological services (Direction des Affaires Culturelles de Corse-DRAC), and metadata can be easily checked thanks to the free access Patriarche geo- 
database web mapping application. The mapping of the sites can then be used in the field to answer multidisciplinary questions related to both local and general landscape evolution.
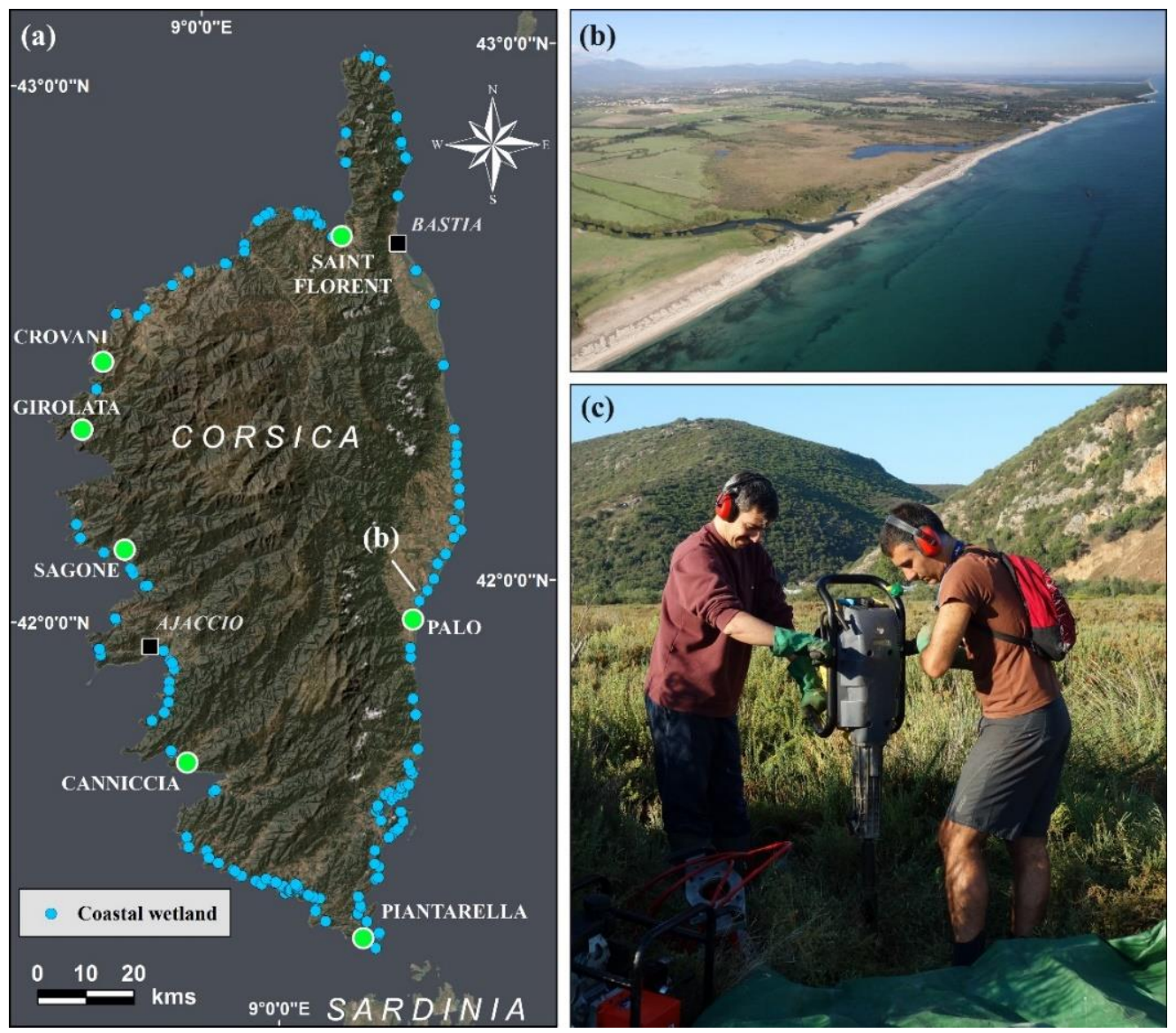

Figure 2. Coastal wetlands of Corsica investigated for palaeovironmental purposes. (a) Location map of the coastal wetlands (blue circles), and the study sites for the present paper are marked with a green circle. (b) is an oblique view of the Gradugine coastal wetland (eastern Corsica), situated to the north of the Abatesco River mouth. (Credits: M. Luccioni). (c) The vibrocoring technique (Credits: M. Ghilardi).

\subsection{Sediment Sampling Techniques}

The height of aquifers within coastal environments limits the number of efficient sampling techniques available. Vibrocoring (Figure 2c) is one technique that permits the collection of sediments in airtight tubes, an essential step to avoid contamination of the sampled material. The most appropriate season for collecting samples is at the end of summer when coastal wetlands are generally dry due to very low aquifer levels. Pipe length is $1 \mathrm{~m}$, and in the stable tectonic context of Corsica, the first six meters of sedimentation correspond to the last six millennia. In general, slight sediment compaction is observed when using the vibrocoring method due to the fine-grained material that deposits in coastal wetlands, and this parameter must be taken into account in subsequent depth/age models. Accurate levelling of boreholes is another important step, notably for palaeo sea-level curve reconstruction, and different techniques can be employed, such as Differential Global Positioning System (DGPS) or Total station.

\subsection{Sedimentological and Geochemical Proxies}

Among the different sedimentological methods, granulometry is important since it allows to determine the energy of deposition. Depending on the size of the sediments, different techniques can be employed: when the fraction is below $2 \mathrm{~mm}$ in size, LASER 
granulometry can be adopted. The preparation of the samples is crucial and includes the removal of both the organic matter and the carbonate contents using different chemical treatments $[75,76]$. Laser determination of sediment texture is accurate and fast, and different statistics and indexes (mean, mode, sorting index, skewness, etc.) can then be calculated using specific software. When the sediments include a fraction greater than $2 \mathrm{~mm}$ in size, the hand-sieving technique (under wet or dry conditions) is generally employed in conjunction with the LASER technique for the fraction below $2 \mathrm{~mm}$.

In addition to sediment granulometry, organic matter and carbonate contents are also measured following standard protocols [77]. Rich organic layers are often encountered in sediments deposited in coastal wetlands, and they generally contain well-preserved bioindicators, such as grains of pollen, plant remains, wood and charcoals.

Geochemical and mineralogical analyses are often used to define the mineral elements composing sediments from coastal wetlands, which helps reconstruct their Holocene sedimentological environmental changes [78]. The geochemical behaviour of trace elements in natural systems may often reflect changes in the chemical, biological and physical conditions of the environment [78,79]. Numerous techniques are employed, with X-ray Diffraction (XRD) and X-ray Fluorescence (XRF) preferred for bulk samples in particular. A more complete technique uses the I-Trax XRF core scanner, which is often used to scan full sections of cores. Measurement intervals show a very high resolution (millimetric) and help to reconstruct with accuracy all the variations of mineral concentrations [80]. In particular, K, Si and Ti are appropriate for evaluating detrital activity [81], and the Ti/Si ratio [81] has also been used to successfully reconstruct the detrital input in the Crovani coastal pond (NW Corsica).

\subsection{Environmental Magnetism}

Environmental magnetism has mainly been used to study lakes, which have long been recognized as repositories of magnetic palaeoenvironmental information [82]. There are some characteristics in common with its application to coastal wetlands: materials eroded in a catchment basin are subsequently transported and then accumulated into a wetland where generally calm conditions prevail. This makes it possible to identify erosional crises. The deposited sediments exhibit some form of magnetic behaviour, and as iron is one of the most common elements in the Earth's crust [83], this justifies the need to incorporate magnetic studies into reconstructions of past global changes. Identifying different sediment sources based on their magnetic properties is a possible approach when investigating coastal wetlands [84], in particular, to distinguish between local (colluvial) and regional (river system) origin [85]. Environmental magnetism can also be successfully applied to archaeology, in particular for the detection of buried sites or for the identification of palaeosoils [86]. In general, magnetic parameters are used in combination with other sedimentological proxies such as grain-size distribution in order to evaluate the dependence of the signal compared to the size of the magnetic minerals. Laboratory techniques can be processed fairly quickly and produce a wide range of results dealing with the presence and concentration of magnetic minerals, which can help reveal palaeoclimate events, for example. In Corsica, the geology is largely composed (two-thirds of the island) of crystalline rocks (granites), exhibiting a wide range of magnetic signatures. The magnetic behaviour of all granites and their eroded material can therefore be well characterized.

\subsection{Radiometric Measurements}

The most common method used to date different sedimentological environments is based on radiocarbon dating. The technique of Accelerator Mass Spectrometry (AMS) is generally employed for dating small quantities of biological remains contained in the sediments.

The calibration process is another important step, in particular for the marine to brackish fauna, and requires correction of what is known as the "marine reservoir effect." Although the integration of cosmogenic radiocarbon into the atmosphere is almost immedi- 
ate, exchanges with the marine environment and within masses of water are more complex and less rapid. Samples formed in the oceanic mixed layer are generally several hundred years older than their atmospheric counterparts, after proper correction for isotopic fractionation [87]. This results in a diminished content of radiocarbon in marine organisms, and this ageing is called the "reservoir effect." If a correction is not applied to the samples, the dates of the marine materials will present ageing or an "apparent age" of about 400 years [88]. In order to calibrate the radiocarbon age of a marine sample, it is necessary to apply a correction for regional variation from the marine reservoir age, $\Delta \mathrm{R}$, and to calibrate using a marine calibration curve, as first proposed by Stuiver et al. [89] and regularly updated since [90]. For Corsica, the marine reservoir effect is well constrained [91].

\subsection{Bioindicators}

\section{- Micro and macrofaunal remains}

Micro and macrofaunal remains are the best materials for directly determining salinity fluctuation prior to characterizing the type of connection with the open sea and the degree of confinement. Definition of characteristic assemblages for marine, brackish and freshwater environments is therefore crucial to precisely reconstruct the evolution of coastal landscapes. Specialists in the identification of molluscs, ostracods, foraminifera and diatoms are involved in this aspect of the geoarchaeological approach.

\section{- $\quad$ Pollen and NPP identifications}

Not all coastal wetlands lend themselves to the accurate, palynology-based reconstruction of vegetation history. In particular, those associated with river deltas can be largely influenced by considerable deposition of older materials originating across the whole catchment area (from alluvial terraces, for example). The procuration of continuous palynological series is difficult in such environments, and the frequent detrital input brings reworked materials via continental and/or marine dynamics. As such, the most appropriate environments for conducting pollen identification of homogeneous sediments (that is, showing no hiatus in sediment accumulation) in Corsica are the lagoons and coastal ponds that formed parallel to the shoreline behind a coastal barrier and were mainly formed by marine-to-coastal dynamics.

The clayey-silty fraction of sediments is generally investigated for pollen grains and determination of NPPs. NPPs record former environmental conditions, allowing to assess trophic stage, moisture conditions, dry phases, pastoral activities, disturbances and erosion within the study area [68]. The aim of identifying pollen is to reconstruct past vegetation composition and to evaluate the direct impacts of past land use and climate changes. Evaluating spatial resolution of palynological data is quite complex since most of the pollen contained in a given sample can originate from very local to very widespread sources due to aeolian processes. The reliability of pollen determination and subsequent interpretation depends on a minimum concentration of pollen grains. To evaluate the direct evidence of cereal cultivation, identification of the pollen of Cerealia-type is the most relevant procedure. However, it must be noted that soil disturbance due to human activities can also be deduced indirectly from the presence of herbaceous taxa (ruderals) concurrent with the opening of woodlands. In addition to cereal cultivation, pastoral activities can be evidenced by the identification of NPPs where generally coprophilous fungi such as Sporormiella or Sordaria are well preserved in the sediments. Again, indirect evidence can be obtained by the identification of nitrophilous plants that are indicative of grazing activities. Over the last three decades in Corsica, coastal wetlands have been intensively investigated to reconstruct vegetation history [69-71,92]. However, it is only during the last decade that robust chronostratigraphy has been used to explore Human-Environment interactions at a high temporal resolution.

- Anthracology and fire signal reconstruction based on microcharcoals

The charcoal concentration in sediments is often regarded as a direct impact of human activities on vegetation cover. Fire is both a natural phenomenon and a human tool, used, 
for example, to clear and maintain open agro-pastoral areas since at least the Early Neolithic [93]. Charcoal count and shape are needed on continuous sediment series in order to reconstruct fire signal. The quantification of fire frequency from sedimentary macrocharcoal is a relevant method used to study human impact on ecosystems throughout the Holocene; however, this method appears to be spatiotemporally limited [93]. Microcharcoals are generally studied at the same time as pollen identification. The threshold between the largest carbonized fragments and the microcharcoal size definition ranges from $60 \mu \mathrm{m}$ [94] to $80 \mu \mathrm{m}[95]$ and finally to $150 \mu \mathrm{m}[93,96]$, depending on the type of environment. In Corsica, neither anthracological studies nor fire signal frequency have been conducted in coastal areas. However, this promising field of research is bound to extend into these zones in the near future, as is already the case for the study of Human-Environment interactions in Corsican Mountain areas [95].

\subsection{Geophysical Surveys: Imageing the Subsurface and Completing Borehole Stratigraphy}

Geophysics is widely employed when investigating subsoil stratigraphy. Among the different methods and techniques commonly applied for archaeometry (geoeletricity, magnetometry, radar, etc.), Electric Resistivity of Tomography (ERT) is quite efficient in coastal environments. This method helps to obtain contrasted values in terms of conductivity/resistivity of the subsurface and is of obvious interest for both archaeologists and specialists of stratigraphy. In general, coastal wetlands are characterized by the accumulation of fine material ranging from clays to coarse sands (and even gravels) and thus exhibit a low resistivity signal. In contrast, the palaeosurface, or margins of the wetland, is composed of harder material such as bedrock or Pleistocene unconsolidated material (fans, screes, etc.), which exhibit high resistivity values. For example, ERT sections established in the Lower Sagone Valley revealed a thick deposition of fluvio-deltaic deposits (low resistivity values) overlying a granitic outcrop, which itself exhibited high resistivity values (Figure 3, [97]). In addition to revealing the main elements of stratigraphy, ERT helps correlate borehole chronostratigraphy by establishing ERT profiles that pass through the core location (Figure 3a). Anomalies that may correspond to archaeological structures embedded within coastal wetland sediments can also be revealed using the ERT method. Indeed, there is a clear multidisciplinary interest in using geophysical methods and techniques for this purpose. The choice of a particular method or technique largely depends on subsoil composition (water saturation, for example) and on expected vertical resolution. Geophysicists, archaeologists and stratigraphers are increasingly adopting a geoarchaeological approach when characterizing both the surface and subsurface of coastal wetlands.

4.8. The Use of GIS for Computing the Multidisciplinary Dataset and for Developing 3-D to 4-D Palaeolandscape Modelling

Starting and ending a geoarchaeological study with GIS may appear to be self-evident: the integration of georeferenced surface and subsurface multidisciplinary data helps to better reconstruct changing landscapes. Two-dimensional information derived from geophysical profiles and borehole stratigraphy is then associated with the accurate dating of the different environments of deposition. In doing so, 3-D and 4-D reconstructions become possible and permit to obtain a precise view of the whole landscape configuration through time, into which local sites can be integrated. 


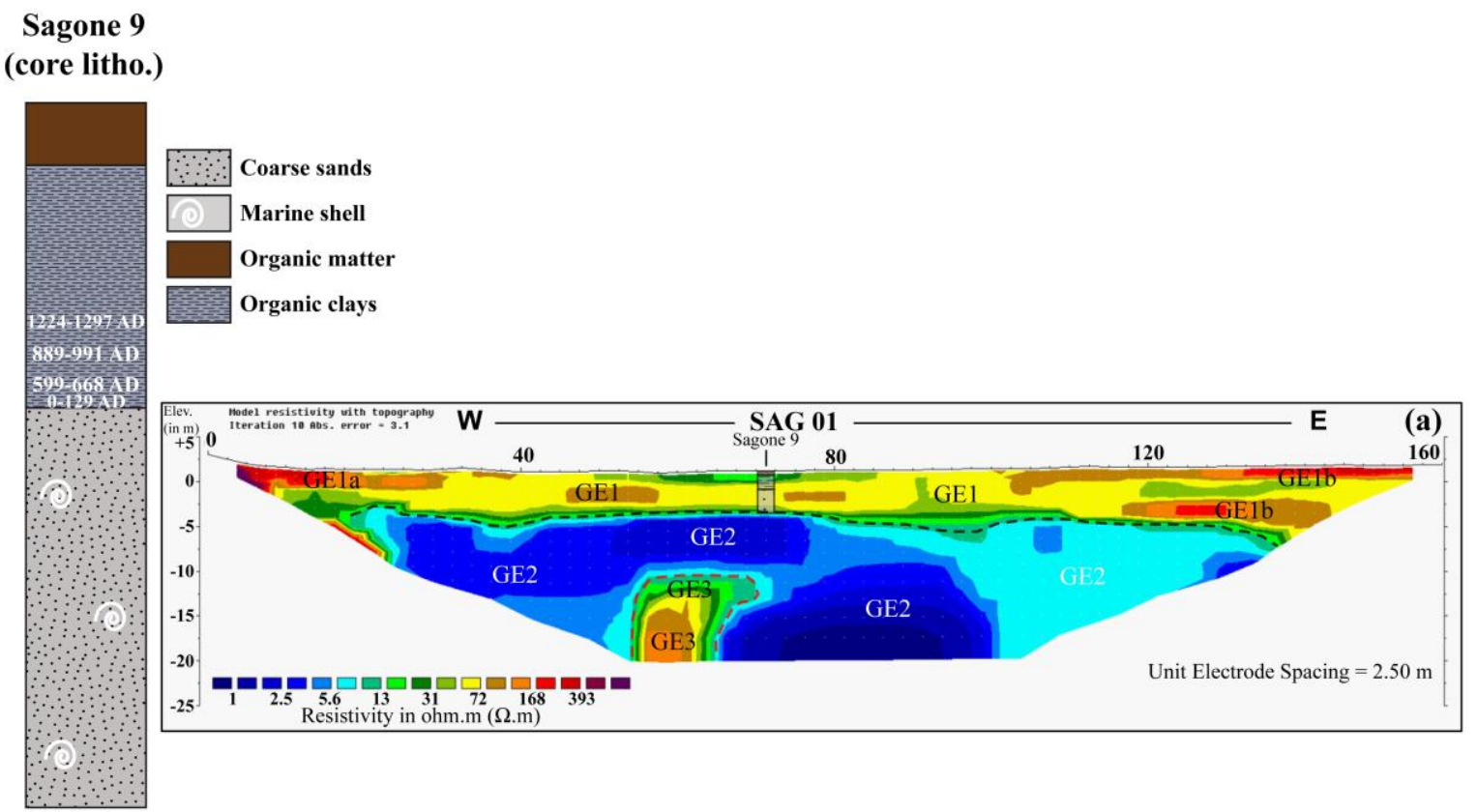

Figure 3. Core lithology and Electric Resistivity Tomography profile (a). The investigation depth is about $20 \mathrm{~m}$, and the core Sagone 9 is situated in the middle part of the profile, enabling us to relate the electrical signal to the granulometry. A first geoelectric unit (GE1, Figure 3a), which is found between the surface and ca. $2.5 \mathrm{~m}$ below mean sea level (bmsl), exhibits generally intermediate resistivity values (20-200 $\Omega \mathrm{m})$. The stratigraphy of core Sagone 9 indicates the presence of marine coarse sands from ca. 1 to $3 \mathrm{~m}$ below sea level (from 2 to ca. $4 \mathrm{~m}$ below the surface). Superficial high resistivities $(>400 \Omega \mathrm{m})$ at the western edge (GE1a, Figure 3a) are attributable to the granitic bedrock associated with coarse-grained material (footslope deposits). The easternmost part of the first geoelectric unit (GE1b, Figure 3a) reveals an increase of the signal (locally $>200 \Omega \cdot \mathrm{m}$ ) in two horizontal layers: the first at the surface and the second at ca. $3 \mathrm{~m}$ bmsl. The second geoelectric unit (GE2, Figure 3a) shows very low values $(<10 \Omega \cdot \mathrm{m})$ and is found below unit GE1, around $5 \mathrm{~m}$ in depth. It consists of sands, and it is noteworthy that the top of Unit GE2 corresponds to the upper limit of the aquifer, which contains haline particles. The third geoelectric unit (GE3, Figure 3a) is at a depth of $12 \mathrm{~m}$ below the surface (10 m below present-day sea level), just west of the midpoint of the SAG01 ERT profile and could be interpreted as a part of the granitic bedrock.

\section{Results}

Corsica island represents a nice example of coastal geoarchaeological works and can be considered in the near future as a model to follow for the other Mediterranean islands in order to reconstruct interactions between past human societies and environmental changes.

\subsection{Palaeogeographic Reconstructions: The Need to Integrate Sites into Their Broader Palaeoenvironmental Context to Enrich Archaeological Knowledge}

One of the major challenges of coastal geoarchaeology is the need to reconsider the history of human occupation at a larger landscape scale than that of the site itself. This requires reconstructing landscape evolution using a high chronological resolution in order to enable accurate evolution of the full palaeoenvironmental conditions. To reach this objective, multiple cores and a relatively high number of radiocarbon dating are required to precisely date both the palaeoenvironments and the point of changeover between the main geomorphological sedimentary units (marine, lagoonal, freshwater pond, etc.). Subsequently, chronostratigraphic cross-sections are established, also using geophysical results: the cross-combination of chronostratigraphy and geophysical surveys thus helps to first reconstruct the 2-dimensional sediment features and then to propose a 3-D interpretation of landscape evolution.

Corsica's most emblematic archaeological symbols are undoubtedly its anthropomorphic menhir statues, which are thought to date from the beginning of the Final Bronze Age (1200-800 cal. BCE). The exact dating of these monoliths is a matter of debate $[98,99]$, 
with the Late Bronze Age (1350-1200 cal. BCE) also being proposed. Many questions have arisen concerning the exact significance of these statues, which are made of granite, the predominant rock of the island, and portray human morphology and weapons [100]. Various assumptions have been made suggesting that they represented chiefs of local tribes or that they delineated territorial boundaries or the location of a major road [98,99]. However, it was not until the mid-2000s that specific environmental conditions were proposed to explain the exact location of these menhir statues $[98,99,101]$. In short, many theories have been proposed and debated concerning their precise origin, location and significance, but with little supporting palaeoenvironmental evidence, even if the presence of water may be a determining parameter. Indeed, most of them are adjacent to springs, river channels and wetlands, and it is thought that the menhir statues may have had a "protective" role in preventing water resources from silting up [98,99].

In the Lower Sagone Valley (SW Corsica), a large deltaic plain formed over the last three millennia [97], even if the present-day landscape configuration indicates no coastal wetlands (lagoons or ponds). Archaeological studies have identified numerous anthropomorphic menhir statues on the west bank of the Sagone River [102], some of which were reused in medieval structures (Figure $4 a-c$ ) or otherwise removed from their original location (Figure $4 d$ ).

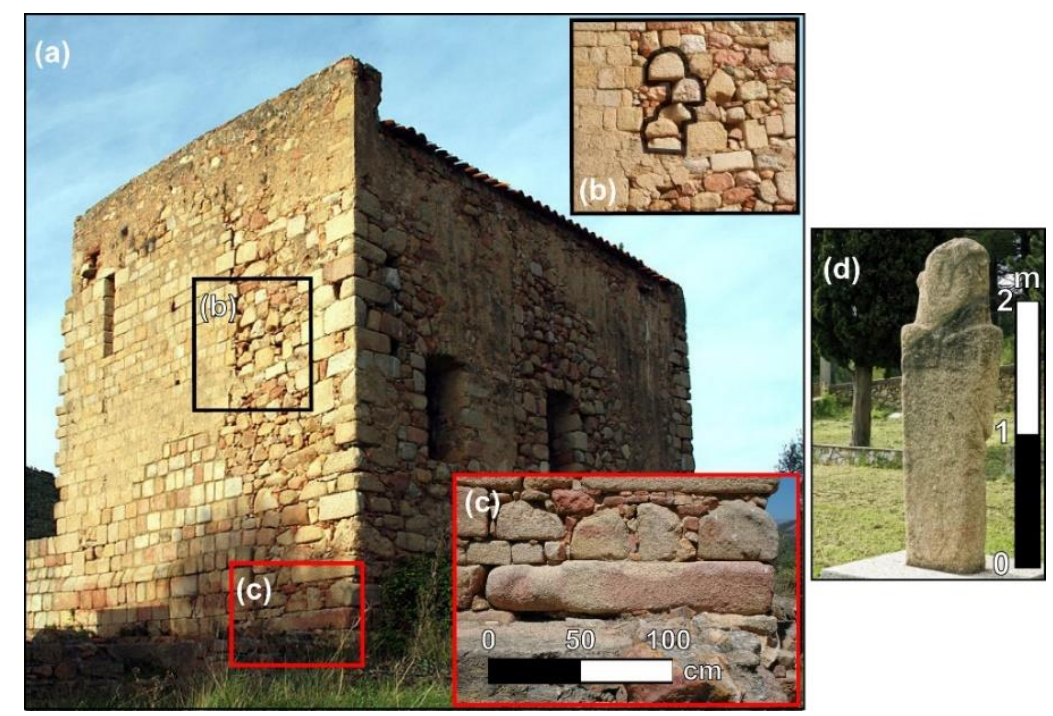

Figure 4. Archaeological evidence for the occupation of the Lower Sagone Valley. Sant'Appianu Cathedral view (a) with reuse of menhir statues as foundation stones (b,c); Menhir Statue of Apricciani (d).

Palaeoenvironmental research conducted in the mid-2010s [97] was based on coring evidence. A mechanism of rapid deltaic progradation starting ca. $800 \mathrm{cal}$. BCE was revealed and was probably partly caused by the $2.8 \mathrm{ka}$ BP ongoing climatic deterioration, which provoked the initial large-scale phase of deltaic progradation of large rivers situated on the north Tyrrhenian coast [103-105]. Surprisingly, the coring results also indicate the existence of a freshwater environment on the west bank of the present-day river bed where the menhir statues were discovered (Figure 5). The base of this freshwater environment has not yet been reached (it dates at least from the beginning of the Middle Bronze Age, ca. $1700 \mathrm{cal}$. $\mathrm{BCE})$, but a clear transition from a coastal freshwater wetland to a marine environment has been dated at ca. $1100 \mathrm{cal}$. BCE (Figure 5 [97]). The complete palaeogeographic reconstruction of the Sagone deltaic plain first aimed to better understand the landscape evolution and then to precisely evaluate changing environmental conditions from the beginning of the Middle Bronze Age (MBA) until modern times (Figure 5), with a specific focus on the supposed period of appearance of the menhir statues during the Late (LBA) or Final Bronze Age (FBA). 

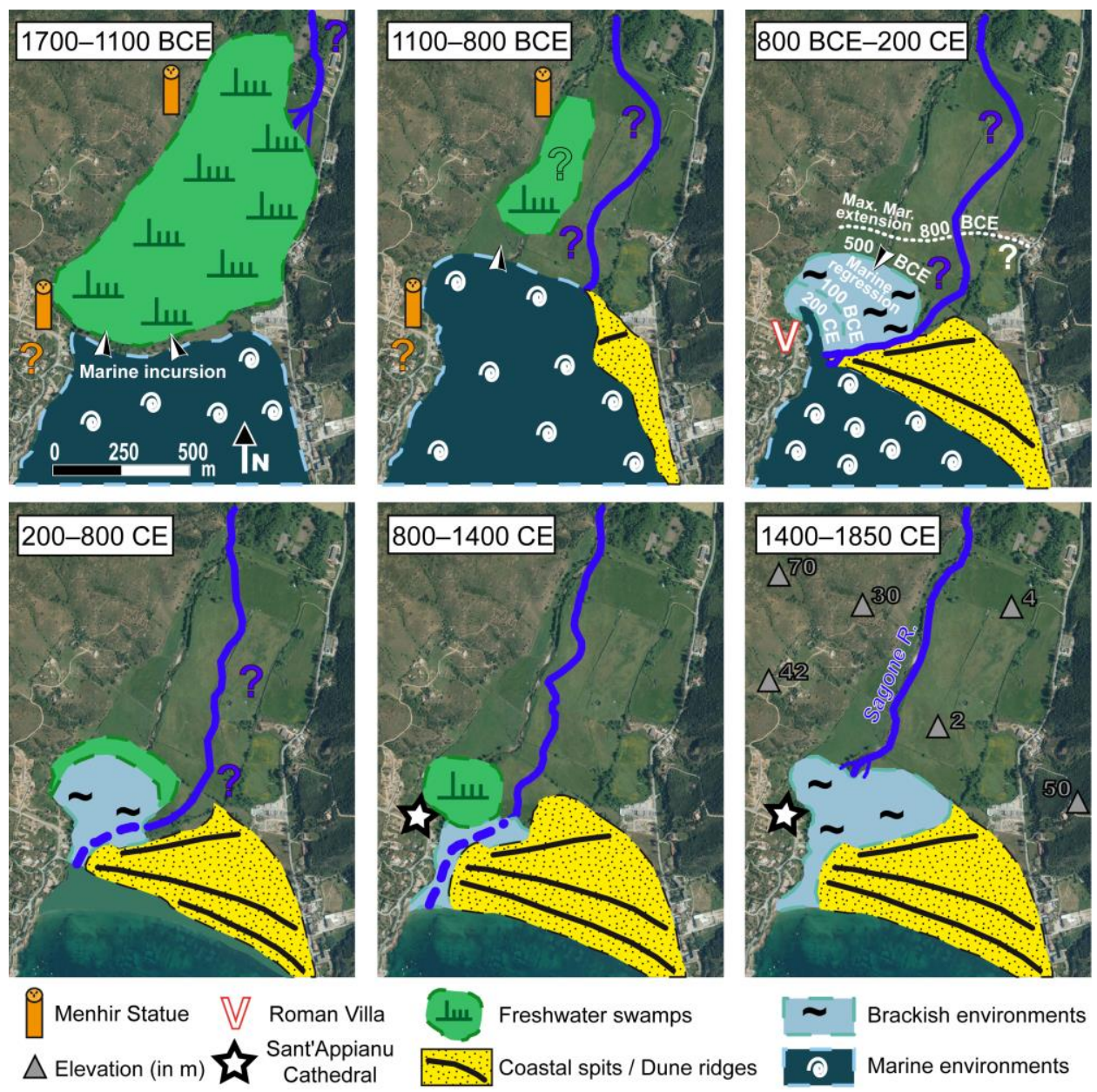

Figure 5. Palaeogeographic reconstruction of the Sagone Plain from the Bronze Age to Late Modern times. The interpretation is based on the combination of sedimentological data and ERT measurements obtained for the present study, together with the 1970s boreholes drilled for geotechnical purposes.

These results make it clear that a freshwater environment prevailed before marine ingression dated ca. 1100-1000 cal. BCE. It is noteworthy that several short episodes of marine incursion had already occurred ca. 1200-1100 cal. BCE (FBA), resulting in the deposition of marine-sandy layers in the rich organic clays of the swamp (Figure 6).

In terms of land use, pollen results reveal that the LBA (1350-1200 cal. BCE) contrasts with the MBA in the sharp decline of both cereal cultivation and pastoralism (Figure 6) around 1350 cal. BCE. Pollen and NPP data (Figure 6) clearly suggest a phase of less human occupation at the end of the Middle Bronze Age and spanning the entire Late Bronze Age. However, the freshwater-coastal pond existed during both periods and thus cannot be used as an environmental argument to explain a sudden change in social organization.

The case study presented here for the Lower Sagone Valley landscape evolution demonstrates the necessity to investigate archaeological questions by adopting a geoarchaeological approach. On this point, it is important to note that continuity of the human occupation is attested at the same location from the Recent Bronze Age until the medieval times and thus obviously indicate that the environmental (topography and specific landscape) configuration played a major role in the installation of sites. 


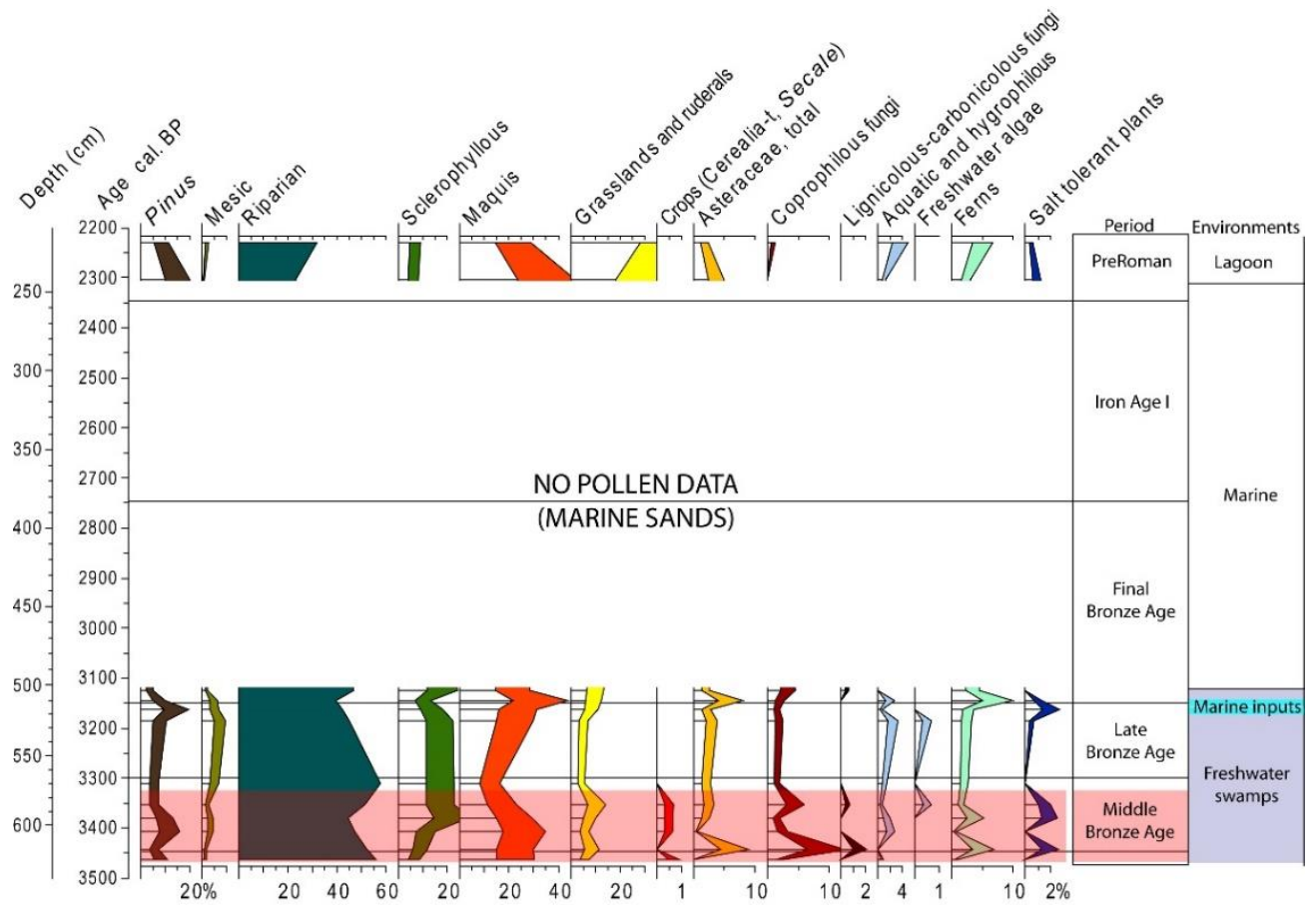

Figure 6. Synthetic pollen diagram reconstructed for the Lower Sagone Valley.

5.2. Reconstructing Vegetation History, and the Importance of Studying Anthropogenic Markers to Enlarge Knowledge of Human Occupation and Land Use

Coastal areas of Corsica have recently been investigated to reconstruct their vegetation history with a specific focus on anthropogenic markers [73]. Pollen diagrams that include a wide range of taxa (mainly opposing Arboreal Pollen (AP) and Non-Arboreal pollen (NAP)) are frequently produced to evaluate the opening of the forest. In Corsica, the dominant taxon during pre- or low- anthropized environments is Erica, as suggested by the invaluable research conducted by $\mathrm{M}$. Reille $[69,106]$. The high representation of this taxon along the shore, reaching 60 to $80 \%$ of the total taxa, is indicative of undisturbed environments where climate forcing is the predominant factor controlling vegetation composition. In Early Neolithic times, representation of Erica decreased rapidly, and open forest vegetation prevailed [71], with the development of Quercus ilex [106]. Meanwhile, anthropogenic activities increased and are characterized by the development of pastoral activities within an open forest context, followed by cereal cultivation [71].

The freshwater wetland revealed in the Lower Sagone Valley (Section 4.1) records important agricultural practices: pastoral activities are well attested at the end of the Early Bronze Age (EBA) and during the MBA, with lower evidence during the LBA and FBA. Indeed, cereal cultivation appears during the MBA, but there is no evidence of this activity during the LBA and FBA based on the study of bioindicators (Figure 6). In this case, palynology has helped identify a clear human presence during the Bronze Age, despite the lack of known archaeological sites in this area. Taken together, the palaeogeographic reconstruction and vegetation history of the Sagone coastal plain reveal a completely different landscape configuration than today's and help to define past territories, in particular those of the Bronze Age. Questions regarding the environmental conditions that prevailed during the probable installation of the menhir statues (presumed to date from the beginning of the FBA) deal with the existence of a freshwater wetland threatened by post-glacial sea-level rise and by frequent brief episodes of marine incursions. The latter may have altered water quality during the LBA. The subsequent increase of salinity may well have provoked a reduction in the size of the freshwater wetland, and at the same time, would have compromised the cultivation of crops, as is suggested by the decrease in Cerealia-type pollen, which began towards the end of the MBA [97]. To summarize, 
palaeoenvironmental research conducted in the Sagone coastal plain posit the installation of the anthropomorphic statue menhirs in close proximity to a freshwater water resource, presumably under environmental threat (alteration of water quality due to frequent haline inputs), and thus agree well with recent archaeological theories $[98,99]$. The geoarchaeological approach adopted here was conducted at the scale of the palaeo-landscape feature (wetlands) and significantly contributes to enriching archaeological knowledge. It is evident that archaeological questions regarding present-day landscape configuration cannot be solved by archaeology alone, which justifies the need for a multidisciplinary approach based on borehole studies when investigating past Human-Environment interactions.

The eastern coast of Corsica provides another example dealing with coastal geoarchaeology. In this area, several lagoons and brackish ponds are seasonally disconnected from the sea. Both archaeological and historical evidence that could be used to document simultaneous early occupation and land use are scarce. In general, such information dealing with agricultural practices is largely dependent on the discovery of tools during excavations. However, little evidence has been uncovered about past farming activities in this area, even if the coastal wetlands were fertile lands and represented possibilities for cereal cultivation and grazing. As a good example of such geoarchaeological research, the Palo coastal pond (Figure 2a) in the southern part of the eastern plain of Corsica was recently investigated for both palaeogeography and pollen reconstruction [71]. It is the fourth largest coastal wetland of the island, covering an area of ca. $212 \mathrm{ha}$. The most ancient traces of a site are situated further west, on a hilltop some distance from the shore, and date back to medieval times (Covasina Castle) [107]. Interestingly, there was much speculation around an earlier occupation, dating from Roman times [108], but the negligible archaeological material found in the NW part of the Palo brackish pond could not attest to clear site development. A decision was then made to reconstruct the landscape evolution for the northern part of this coastal wetland and to investigate the existence of possible human presence and land use during Roman times and earlier periods. A borehole was drilled in the northern part of the Palo pond, where surficial archaeological material had previously been identified [108], and pollen studies were conducted on this 3000-year sedimentary sequence [71]. Pollen grain studies together with NPP identification (Figure 7) highlight pastoral activities during the first half of the 1st millennium BCE (corresponding to Iron Age I) as well as intensive livestock breeding during medieval times and under the occupation of the Genoese from the 15 th to the 18 th c. CE.

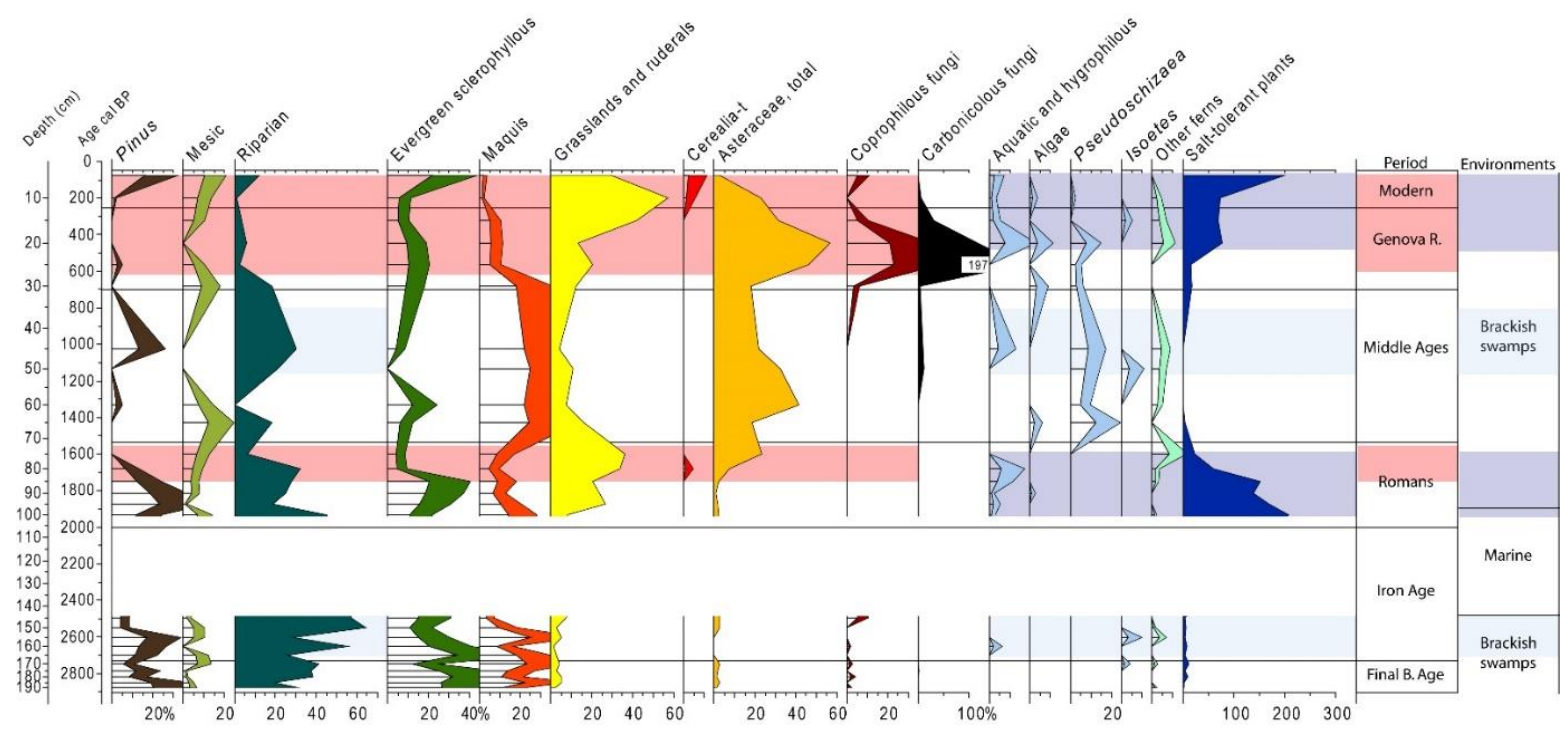

Figure 7. Synthetic pollen diagram established for the Palo pond sequence [61]. A period of cereal cultivation is dated to Late Roman times and also corresponds to an increase of ruderal plants and to a decrease in the arboreal taxa. Note the high representation of coprophilous fungi, suggesting intense pastoral activities during the Late Middle Ages and under the administration of the Genoese Republic. 
This information is in good agreement with archaeological and historical evidence derived from the occupation of the nearby Covasina castle. However, the idea of a possible human presence during the Iron Age is a novel feature. The most interesting finding was the discovery of crop cultivation during Late Roman times in the northern part of the Palo pond, where archaeological material was discovered a short distance (about $1 \mathrm{~km}$ ) away to the NW. Very recently, in 2020, archaeological surveys were conducted at the Chiarata site (situated $3 \mathrm{~km}$ to the NW of the coring site), and the associated excavations revealed the presence of buildings made of rounded cobbles and the bases of two earthenware dolia (Figure 8), which have been dated to Mid-to Late Roman times. This discovery suggests the storage of goods associated with agriculture. On this point, archaeological findings confirm palynological results.

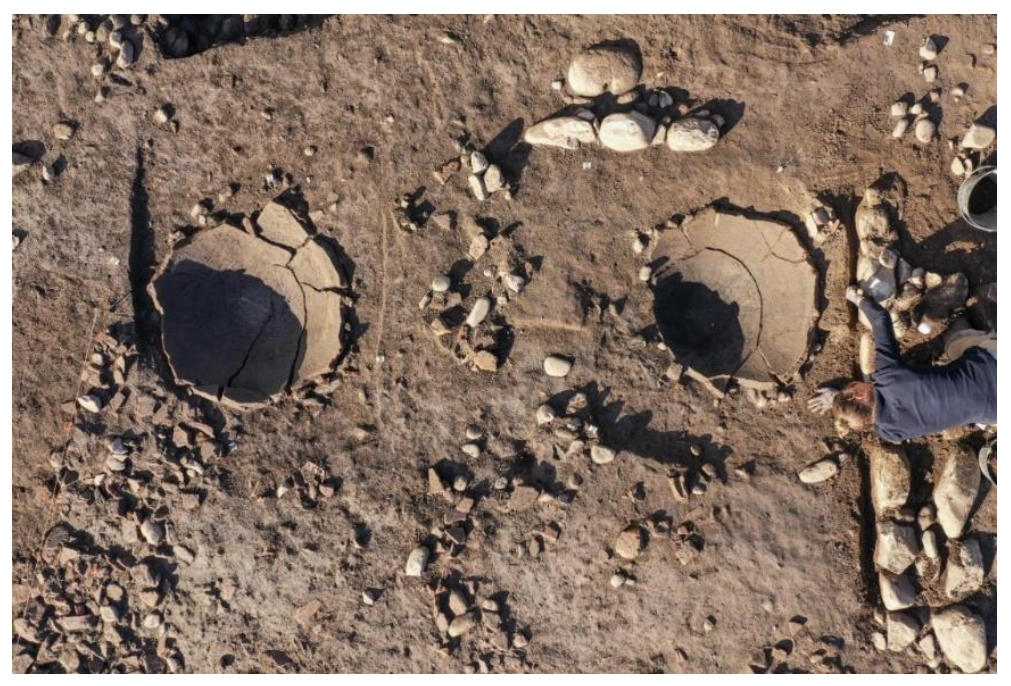

Figure 8. Aerial view of the Chiarata site where the bases of dolia were discovered in 2020 (credits: INRAP). Accurate dating of these archaeological vessels used for the storage of goods has not yet been defined, but they can reasonably be attributed to the second half of Roman times. The existence of these earthenware storage containers supports pollen investigations indicating cereal cultivation during Late Roman times.

\subsection{Geoarchaeology as a Tool for Debating the Role of Climate Changes and Associated Environmental and Societal Impacts: A Case Study from the Holocene RCC Events}

The Holocene spans the last 11,700 years and is regarded as a period of generally warm climate conditions following the last glacial and late-glacial periods. However, a series of abrupt climate changes known as the Rapid Climate Changes (RCCs) [109] or Bond $[110,111]$ events are associated with increased aridity and/or colder temperatures and have been evidenced notably in the Eastern Mediterranean. During the last decades, these "abrupt" climatic alterations were thought to be a major cause of the collapse of ancient civilizations, leading to the development of the concept of collapsology [112,113]. Environmental and climatological determinism has since been widely adopted and is strongly based on the over-interpretation of geosciences data. By definition, little consideration is given to human resilience strategies by collapsologists, despite the important research done by Human Sciences specialists (archaeologists, anthropologists, historians, etc.) to point out the adaptation of past human societies to changing environmental crises. In particular, climatic changes, such as droughts, are considered as determining events for abrupt changes in societal organization. Among the different droughts recorded during the Holocene, the 8.2 [114], 4.2 [115,116] and 3.2 [29,30,117,118] ka BP RCC events have been investigated over the last decades for their impacts on past human societies, mostly in the Eastern Mediterranean. The literature on this topic is relatively abundant, in particular, for the Eastern Mediterranean [29] and the Levant [30]. 
However, little attention has been paid to the Western Mediterranean and, in particular, to the insular environments. Over the last few years, important research (part of the CNRS research programme MISTRALS) has been conducted in the coastal wetlands of Corsica to attempt to identify specific sedimentary signatures and societal responses to these climate events. On the western coast of the island, the coastal ponds of Canniccia, Girolata and Crovani (Figure 2a) have been the focus of attention, and evidence of high detrital input has been recorded by reconstructing their sedimentary history. All these sites confirm that around 1350-1100 cal. BCE (Figure 9a-c), a phase of thick deposition of terrestrial sediments occurred due to increased runoff which reinforced the alluvial/colluvial activity. For approximately two and a half centuries, intense wet conditions (episodes) were observed in Corsica, while during the same period (300 years) in the Eastern Mediterranean, a contrasting arid phase is evidenced $[30,118]$. All the palaeoenvironmental records derived from borehole sequences obtained in western Corsica suggest a phase of important detritism on the western coast around the $3.2 \mathrm{ka}$ BP RCC event. It is noteworthy that, in southern France, similar terrestrial input has been observed in the Rhone valley [119] and in the northern Pyrenees [120]. This appears to confirm that an "abrupt" regional climate change affecting the Western Mediterranean can be identified and linked to the strengthening of sediment accumulation in river valleys and coastal ponds. The climate mechanisms of this strong terrestrial input remain largely unknown. Nonetheless, the societal responses to these natural phenomena must be taken into consideration, rather than systematically assuming a non-resilience to the changing environmental conditions.

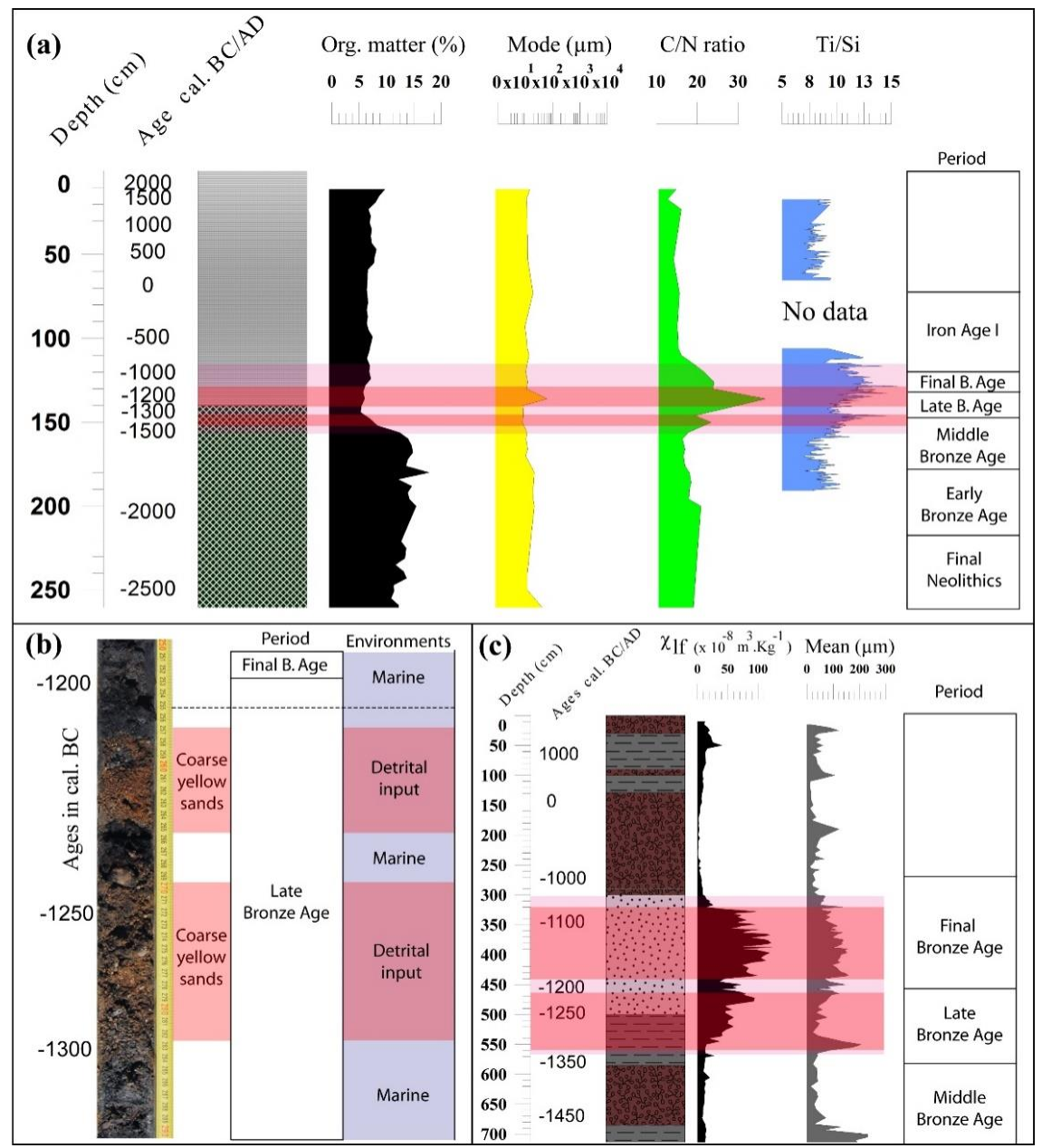

Figure 9. Core chronostratigraphy for Crovani (a), Girolata (b) and Canniccia (c) sites. sedimentological (laser granulometry and organic matter content), geochemical (C/N and Ti/Si rates) and magnetic (magnetic susceptibility at low frequency) parameters were included. 
It must first be noted that the increase of rainfall provoked detrital input into the coastal wetlands of Canniccia, Girolata and Crovani and reinforced the alluvial activity (the Taravo River in the case of the Canniccia Pond; Figure 9c).

It is noteworthy that this sediment deposition is not homogeneous and reveals at least two major phases of sediment input around the $3.2 \mathrm{ka}$ BPP RCC event (Figure 9), which clearly indicates that multiple climatic events impacted the sedimentation processes. Indeed, the chronostratigraphy derived from ${ }^{14} \mathrm{C}$ dating of peat material is quite well constrained: detritism starts at the beginning of the Late Bronze Age and lasts until the beginning of the Final Bronze Age, with the highest peak recorded between 1300 and 1200 cal. BCE (Figure 9a-c). However, uncertainties concerning radiocarbon (uncertainty about radiocarbon dating is around 100-200 years and does not allow for precise comparison between archeological and paleoenvironmental data and the "plateau effect" of the calibration curve) mean that it is not always possible to accurately date these peaks of reinforced detritism when comparing all sites. Thus, the timeline of a climate event may differ from site to site.

Following this, the main task is to determine the origins of erosional processes rather than to strictly base any interpretation of sediment accumulation as a direct consequence of a "sudden" rainfall increase. It is essential to avoid any form of climate determinism that could be exclusively related to the interpretation of palaeoenvironmental data. From a cultural point of view in Corsica, the transition from the Mid- to the Late Bronze Age is characterized by an important societal reorganization of territories [121]: the Middle Bronze Age was a period marked by the development of Castelli and Torre (castles), fortified hilltop sites overlooking adjacent river valleys. These structures were often associated with large buildings for the storage of goods, including grains and seeds. Pollen analyses have confirmed that the MBA was a period of sustained agriculture based on cereal cultivation along valleys situated close to the Corsican shore: this is evidenced by pollen records obtained in the Lower Sagone Valley (Figure 6) and also in the Saint-Florent [71], Girolata and Crovani areas. Towards the end of the MBA, these "castles" were abandoned and sites of human occupation dispersed during the LBA. The menhir statues in several river valleys of the island probably appeared later. The changing strategy of human occupation during the Mid- to Late Bronze Ages involved deforestation followed by cultivation and overgrazing. This had a direct impact on the exposure of the soil on slopes and thus enhanced erosional processes. During this pivotal societal upheaval at the end of the MBA, episodes of heavy rainfall (which probably affected the whole Western Mediterranean) provoked considerable erosion and led to high detrital accumulation in the lower river valleys and, ultimately, the coastal wetlands. The trigger for this detrital crisis, which is observable at a regional scale for western Corsica, must be seen as a succession of complex societal parameters followed by particularly wet climate conditions rather than as the result of the unique climate forcing alone. These societal parameters require further documentation in the future, based on additional site studies. Our study clearly highlights that the regional climatic alteration lasted for 2.5 to 3 centuries at the end of the MBA and that the appearance of the menhir statues seems to be related to specific climate conditions associated with the very wet climate conditions of the LBA and the beginning of the FBA. We thus hypothesize that coastal wetlands represented an important water resource that was subject to constant environmental threats (marine incursions, see Section 4.1, detrital input, etc.), and as such, were probably a matter for conflict between human groups. On this last point, geoarchaeology employs an original multidisciplinary approach enabling us to better understand the mechanisms of environmental changes caused by both natural parameters and societal behaviours.

\section{Discussion/Conclusions}

This paper highlights the interest of studying Human-Environment interactions at a larger scale than that of the sites of occupation themselves and takes into account the fact that the latter were evolving both in time and in the wider geographical/geomorphological/ 
geological contexts. Several case studies from Corsica island are presented here and have demonstrated the necessity to reconsider the geographical scale of study in a coastal environmental context. It is noteworthy that geoarchaeology is not directly dependent on sites of human occupation, thus minimizing taphonomic bias. Geoarchaeology adopts a multidisciplinary approach that aims to reconstruct both landscape changes and anthropogenic actions on environments, but which also examines global societal responses. Coastal geoarchaeology is based on the identification of geographical/geomorphological/geological features along palaeoshorelines, which are common to several sites at a regional scale. In particular, the study of coastal wetlands that were influenced by both continental and marine dynamics of sedimentation has demonstrated the need for a multidisciplinary approach. Indeed, these areas provide a unique opportunity to study geographical and geomorphological systems that were first occupied as early as the Neolithic period in Corsica and Sardinia, for example. Studying complex causalities of environmental impacts and societal responses is a challenging task, and the different case studies presented herein indicate that the notion of socio-environmental transformation of landscape deserves to be broadened. This involves precisely describing the relationships between societies and their environment (including climate) at the local and regional levels. Future discussions should consider a succession of factors in time rather than a mixture of both natural and anthropogenic forcing.

Funding: This research was funded by DRAC Corsica (Programmes Collectifs de Recherche directed by Matthieu Ghilardi for the periods 2013-2015 and 2018-2020) and the CNRS MISTRALS (Workshop PALEOMEX-INEE) national research programme for the period 2010-2020.

Institutional Review Board Statement: Not applicable.

Informed Consent Statement: Not applicable.

Data Availability Statement: Not applicable.

Acknowledgments: The author is grateful to Vassiliki Moslopoulou (NOA, Greece) for providing some of the photographs of the bioerosional notch reported for SW Crete. Kewin Peche Quilichini (INRAP, Corsica) is warmly acknowledged for fruitful discussions on the Bronze Age occupation of Corsica. Special thanks are addressed to Lionel Siame (AMU, France) and Yoann Quesnel (AMU, France), the co-directors of the "Terre et Planètes" research team from CEREGE, for their support. This paper is part of the Habilitation à Diriger des Recherches (University of Aix-Marseille, France) defended by Matthieu Ghilardi on 9 December 2020. Special thanks to Rachel Mackie for polishing the English. Finally, Editor Adriano Ribolini and two anonymous reviewers are acknowledged for providing fruitful comments.

Conflicts of Interest: The author declares no conflict of interest.

\section{References}

1. Cordova, C. Geoarchaeology: The Human-Environmental Approach; Environmental History and Global Change; I.B. Tauris: London, UK, 2018; p. 320.

2. Barnosky, A.D.; Matzke, N.; Tomyia, S.; Wogan, G.O.U.; Swartz, B.; Quental, T.B.; Marshall, C.; McGuire, J.L.; Lindsey, E.L.; Maguire, K.C.; et al. Has Earth's sixth mass extinction already arrived ? Nature 2011, 471, 51-57. [CrossRef]

3. Kolbert, E. The Sixth Extinction. An Unnatural History; Henry Holt and Company: New York, NY, USA, $2014 ;$; p. 319.

4. Butzer, K.W. Adaptation to global environmental change? Prof. Geogr. 1980, 32, 269-278. [CrossRef]

5. Ghilardi, M.; Lespez, L. Geoarchaeology of the Mediterranean islands: From "Lost worlds" to vibrant places. Geoarchaeology of the Mediterranean Islands. J. Archaeol. Sci. Rep. 2017, 12, 735-740.

6. Butzer, K.W. Enviromnent and Archaeology; Aldine, Atherton: Chicago, IL, USA, 1968; p. 703.

7. Dincauze, D.F. Environmental Archaeology. Principles and Practice, 5th ed.; Cambridge University Press: Cambridge, UK, 2006; p. 587.

8. Butzer, K.W. Archaeology as Human Ecology; Cambridge University Press: Cambridge, UK, 1982; p. 364.

9. Bravard, J.P. Géoarchéologie des vallées de Rhône-Alpes depuis le Tardiglaciaire. In Dynamique du Paysage-Entretiens de Géoarchéologie; Bravard, J.P., Prestreau, M., Eds.; Documents d'Archéologie en Rhône-Alpes: Lyon, France, 1995; Volume 15, pp. 129-150.

10. Brown, A.G. Alluvial Geoarchaeology, Floodplain Archaeology and Environmental Change; Cambridge manuals in Archaeology; Cambridge University Press: Cambridge, UK, 1997; 377p. 
11. Brown, A.G. Geoarchaeology, the four dimensional (4D) fluvial matrix and climatic causality. Geomorphology 2008, $101,278-297$. [CrossRef]

12. Arnaud-Fassetta, G. La géoarchéologie fluviale. Concepts, attendus et méthodes d'étude rétrospectives appliqués à la caractérisation du risque hydrologique en domaine méditerranéen. EchoGéo 2008, 4. [CrossRef]

13. Ghilardi, M. Géoarchéologie Fluviale ET Littorale: Contribution à L'identification Des Forçages Naturels ET Anthropiques Dans l'élaboration des Paysages de Mediterranee. Habilitation à Diriger des Recherches; Aix-Marseille University: Marseille, France, 2020 ; Volume 2.

14. Stanley, J.D.; Warne, A.G. Worldwide initiation of Holocene marine deltas by deceleration of sea-level rise. Science 1994, 265, 228-231. [CrossRef]

15. Brückner, H.; Vött, A.; Armin Schriever, A.; Handl, M. Holocene delta progradation in the eastern Mediterranean- case studies in their historical context. Méditerranée 2005, 104, 95-106. [CrossRef]

16. Ghilardi, M. (Ed.) Géoarchéologie des îles de Méditerranée; CNRS éditions Alpha: Paris, France, 2016; 344p.

17. Medail, F. The specific vulnerability of plant biodiversity and vegetation on Mediterranean islands in the face of global change. Reg. Environ. Chang. 2017, 17, 1775-1790. [CrossRef]

18. Colledge, S.; Conolly, J. A review and synthesis of the evidence for the origins of farming on Cyprus and Crete. In The Origins and Spread of Domestic Plants in Southwest Asia and Europe; Colledge, S., Conolly, J., Eds.; UCL Institute of Archaeology/Left Coast Press: Walnut Creek, CA, USA, 2017; pp. 53-74.

19. Vigne, J.D.; Briois, F.; Tengberg, M. Nouvelles Données sur les Débuts du Neolithique à Chypre. Actes de la Séance de la Société Préhistorique Française, Paris, 18-19 Mars 2015; Société Préhistorique française: Paris, France, 2017; Volume 9, pp. 7-11.

20. Willcox, G. Présence des céréales dans le Néolithique précéramique de Shillourokambos à Chypre: Résultats de la campagne 1999. Paléorient 2001, 26, 129-135. [CrossRef]

21. Willcox, G. The origins of Cypriot farming. In Le Néolithique de Chypre. Actes du Colloque International Organisé par le Département des Antiquités de Chypre et l'Ecole Française d'Athènes, Nicosie 17-18 Mai 2001; Guilaine, J., Le Brun, A., Eds.; Bulletin de Correspondance Hellénique: Paris, France, 2003; pp. 231-238.

22. Butzer, K.W.; Harris, S.E. Geoarchaeological approaches to the environmental history of Cyprus: Explication and critical evaluation. J. Archaeol. Sci. 2007, 34, 1932-1952. [CrossRef]

23. Simmons, A.H. Extinct pygmy hippopotamus and early man in Cyprus. Nature 1988, 333, 554-557. [CrossRef]

24. Simmons, A.H. Bitter hippos of Cyprus: The island's first occupants and the last endemic animals—setting the stage for colonisation. In Neolithic Revolution: New Perspectives on Southwest Asia in Light of Recent Discoveries on Cyprus; Levant Supplemantary Series I; Peltenburg, E., Wasse, A., Eds.; Oxbow Books: Oxford, UK, 2004; pp. 1-14.

25. Simmons, A.; Mandel, R.D. Site formation processes at Akrotiri Aetokremnos, Cyprus: Why the site is so controversial? In Géoarchéologie des îles de Méditerranée; Ghilardi, M., Ed.; CNRS Editions Alpha: Paris, France, 2016; pp. 57-72.

26. Kardulias, P.N.; Yerkes, R.W. Flaked Stone Artifacts from the Malloura Valley Survey and their Cypriot Context. In Crossroads and Boundaries: The Archaeology of Past and Present in the Malloura Valley, Cyprus; Toumazou, M.K., Kardulias, P.N., Counts, D.B., Eds.; Annual of ASOR 65; American Schools of Oriental Research: Boston, MA, USA, 2012; pp. 107-124.

27. Peltenburg, E.; Colledge, S.; Croft, P.; Jackson, A.; McCartney, C.; Murray, M. Neolithic dispersals from the Levantine Corridor: A Mediterranean perspective. Levant 2001, 33, 35-64. [CrossRef]

28. Morhange, C.; Goiran, J.P.; Bourcier, M.; Carbonel, P.; Le Campion, J.; Rouchy, J.M.; Yon, M. Recent Holocene paleo-environmental evolution and coastline changes of Kition, Lanarca, Cyprus, Mediterranean Sea. Mar. Geol. 2000, 170, 205-230. [CrossRef]

29. Kaniewski, D.; Van Campo, E.; Guiot, J.; Le Burel, S.; Otto, T.; Baeteman, C. Environmental roots of the Late Bronze Age crisis. PLoS ONE 2013, 8, e71004. [CrossRef]

30. Kaniewski, D.; Marriner, N.; Bretschneider, J.; Jans, G.; Morhange, C.; Cheddadi, R.; Otto, T.; Luce, F.; Van Campo, E. 300-Year drought frames Late Bronze Age to Early Iron Age transition in the Near East: New palaeoecological data from Cyprus and Syria. Reg. Environ. Chang. 2019, 19, 2287-2297. [CrossRef]

31. Pirazzoli, P. The Early Byzantine tectonic paroxysm. Z. Fur Geomorphol. 1986, 62, 31-49.

32. Pirazzoli, P.; Ausseil-Badie, J.; Giresse, P.; Hadjidaki, E.; Arnold, M. Historical environmental changes at Phalarsana harbor, West Crete. Geoarchaeology 1992, 7, 371-392. [CrossRef]

33. Mourtzas, N. Archaeological indicators for sea level change and coastal neotectonic deformation: The submerged Roman fish tanks of the Gulf of Matala, Crete, Greece. J. Archaeol. Sci. 2012, 39, 884-895. [CrossRef]

34. Stiros, S.C.; Blackman, D.J. Seismic coastal uplift and subsidence in Rhodes Island, Aegean Arc: Evidence from an uplifted harbor. Tectonophysics 2014, 611, 114-120. [CrossRef]

35. Desruelles, S.; Fouache, E.; Pavlopoulos, K.; Dalongeville, R.; Peulvast, J.P.; Coquinot, Y.; Potdevin, J.L. Beachrocks et variations récentes de la ligne de rivage en Mer Egée dans l'ensemble insulaire Mykonos-Délos-Rhénée (Cyclades, Grèce). Géomorphologie: Relief Process. Environ. 2004, 10, 5-17. [CrossRef]

36. Mourtzas, N.D. A palaeogeographic reconstruction of the seafront of the ancient city of Delos in relation to Upper Holocene sea level changes in the central Cyclades. Quat. Int. 2012, 250, 3-18. [CrossRef]

37. Mourtzas, N.D.; Kolaiti, E. Holocene sea-level changes and palaeogeographic reconstruction of the Ayia Irini prehistoric settlement (Keos island, Cyclades archipelago, Greece). In Géoarchéologie des îles de Méditerranée; Ghilardi, M., Ed.; CNRS Editions Alpha: Paris, France, 2016; pp. 119-135. 
38. Mourtzas, N. Palaeogeographic reconstruction of the coast of ancient Andros. In Palaiopolis, Andros: Thirty Years of Excavation Research; Palaiokrassa-Kopitsa, L., Ed.; Kaireios Library: Andros, Greece, 2018; pp. 56-66.

39. Kolaiti, E.; Mourtzas, N.D. New insights on the relative sea level changes during the Late Holocene along the coast of Paros Island and the northern Cyclades (Greece). Ann. Geophys. 2020, 63, 669. [CrossRef]

40. Stiros, S. The AD 365 Crete earthquake and possible seismic clustering during the fourth to sixth centuries AD in the Eastern Mediterranean: A review of historical and archaeological data. J. Struct. Geol. 2001, 23, 545-562. [CrossRef]

41. Moslopoulou, V.; Begg, J.; Nicol, A.; Oncken, O.; Prior, C. Formation of Late Quaternary paleoshorelines in Crete, Eastern Mediterranean. Earth Planet Sci. Lett. 2015, 431, 294-307. [CrossRef]

42. Lespez, L. Les dynamiques des systèmes fluviaux en Grèce du Nord au cours des 7 derniers millénaires: Vers une approche multiscalaire des interactions Nature/Société. Géomorphologie Relief Process. Environ. 2007, 1, 49-66.

43. Evelpidou, N.; Pavlopoulos, K.; Vouvalidis, K.; Syrides, G.; Triantaphyllou, M.; Karkani, A.; Paraschou, T. Holocene palaeogeographical reconstruction and relative sea-level changes in the southeastern part of the island of Samos (Greece). Comptes Rendus Geosci. 2019, 351, 451-460. [CrossRef]

44. Pavlopoulos, K.; Fouache, E.; Sidiropoulou, M.; Triantaphyllou, M.; Vouvalidis, K.; Syrides, G.; Gonnet, A.; Greco, E. Palaeoenvironmental evolution and sea-level changes in the coastal area of NE Lemnos Island (Greece) during the Holocene. Quat. Int. 2013, 308-309, 80-88. [CrossRef]

45. Pavlopoulos, K.; Triantaphyllou, M.; Karkanas, P.; Kouli, K.; Syrides, G.; Vouvalidis, G.; Palyvos, N.; Tsourou, T. Paleoenvironmental evolution and prehistoric human environment, in the embayment of Palamari (Skyros Island, Greece) during Middle-Late Holocene. Quat. Int. 2010, 216, 41-53. [CrossRef]

46. Karkani, A.; Evelpidou, N.; Giaime, M.; Marriner, N.; Maroukian, H.; Morhange, C. Late Holocene palaeogeographical evolution of Paroikia Bay (Paros Island, Greece). Comptes Rendus Geosci. 2018, 350, 202-211. [CrossRef]

47. Ghilardi, M.; Vacchi, M.; Currás, A.; Müller Celka, S.; Theurillat, T.; Lemos, I.; Pavlopoulos, K. Géoarchéologie des paysages littoraux le long du golfe sud-eubéen (île d'Eubée, Grèce) au cours de l'Holocène. Quaternaire 2018, 29, 95-120. [CrossRef]

48. Ghilardi, M.; Fachard, S.; Pavlopoulos, K.; Psomiadis, D.; Collana, C.; Bicket, A.; Crest, Y.; Bonneau, A.; Delanghe-Sabatier, D.; Knodell, A.; et al. Reconstructing mid-to-recent Holocene paleoenvironments in the vicinity of Ancient Amarynthos (Euboea, Greece). Geodin. Acta. 2012, 25, 38-51. [CrossRef]

49. Ghilardi, M.; Psomiadis, D.; Pavlopoulos, K.; Müller-Celka, S.; Fachard, S.; Theurillat, T.; Verdan, S.; Knodell, A.; Theodoropoulou, T.; Bicket, A.; et al. Mid- to Late Holocene shoreline reconstruction and human occupation in Ancient Eretria (South Central Euboea, Greece). Geomorphology 2014, 208, 225-237. [CrossRef]

50. Fachard, S.; Knoepfler, D.; Reber, K.; Karapaschalidou, A.; Krapf, T.; Theurillat, T.; Kalamara, P. Recent research at the Sanctuary of Artemis Amarysia in Amarynthos (Euboea). Archaeol. Rep. 2017, 63, 167-180. [CrossRef]

51. Spampinato, C.R.; Costa, B.; Di Stefano, A.; Monaco, C.; Scicchitano, G. The contribution of tectonics to relative sea-level change during the Holocene in coastal south-eastern Sicily: New data from boreholes. Quat. Int. 2011, 232, 214-227. [CrossRef]

52. Basso, D.; Bernasconi, M.P.; Robba, E.; Marozzo, S. Environmental evolution of the Marsala Sound, Sicily, during the last 6000 years. J. Coast. Res. 2008, 24, 177-197. [CrossRef]

53. Leighton, R. Sicily before History. An Archeological Survey from the Paleolithic to the Iron Age; Cornell University Press: Ithaca, NY, USA, 1999; p. 224.

54. Mazza, A. Reconstructing the coastal landscape of Selinus (Sicily, Italy) and Lipari Sotto Monastero (Lipari, Italy). In Géoarchéologie des îles de Méditerranée; Ghilardi, M., Ed.; CNRS Editions Alpha: Paris, France, 2016; pp. 177-190.

55. Marriner, N.; Gambin, T.; Djamali, M.; Morhange, C.; Spiteri, M. Geoarchaeology of the Burmarrad ria and early Holocene human impacts on western Malta. Palaeogeogr. Palaeoclimatol. Palaeoecol. 2012, 339, 52-65. [CrossRef]

56. Pirazzoli, P.; Stiros, S.C.; Laborel, J.; Laborel-Deguen, F.; Arnold, M.; Papageorgiou, S.; Morhange, C. Late-Holocene shoreline changes related to palaeoseismic events in the Ionian Islands, Greece. Holocene 1994, 4, 397-405. [CrossRef]

57. Evelpidou, N.; Karkani, A.; Pirazzoli, P.A. Late Holocene tectonic implications deduced from tidal notches in Leukas and Meganisi islands (Ionian Sea). Geol. Acta. 2017, 15, 1-9.

58. Berger, J.F.; Metallinou, G.; Guilaine, J. Vers une révision de la transition méso-néolithique sur le site de Sidari (Corfou, Grèce). Nouvelles données géoarchéologiques et radiocarbone, évaluation des processus post-dépositionnels. In La transition néolithique en Méditerranée; Manen, C., Perrin, T., Guilaine, J., Eds.; Archives d'écologie préhistorique; Errance: Toulouse, France, 2014; pp. 213-232.

59. Marriner, N.; Morhange, C.; Faivre, S.; Flaux, C.; Vacchi, M.; Milko, S.; Dumas, V.; Boetto, G.; Radic Rossi, I. Post-Roman sea-level changes on Pag island (Adriatic Sea): Dating Croatia's "enigmatic" coastal notch? Geomorphology 2014, 221, 83-94. [CrossRef]

60. Alcover, J.A. Disentangling the Balearic first settlement issues. ENDINS 2004, 26, 143-156.

61. Burjachs, F.; Perez-Olbiol, R.; Picornell Gelabert, L.; Revelles, J.; Servera-Vives, G.; Exposito Barea, I.; Yll, E.I. Overview of environmental changes and human colonization in the Balearic Islands (Western Mediterranean) and their impacts on vegetation composition during the Holocene. Geoarchaeology of the Mediterranean Islands. J. Archaeol. Sci. Rep. 2017, 12, 845-859. [CrossRef]

62. Cherry, J.F.; Leppard, T.P. The Balearic paradox: Why were the islands colonized so late? Pyrenae 2018, 49, 49-70.

63. Simon, M.; Diaz, N.; Solorzano, E.; Montiel, R.; Francalacci, P.; Malgosa, A. Dissecting mithocondrial dna variability of baleraic populations from the bronze age to current era. Am. J. Hum. Biol. 2017, 29, e22883. [CrossRef] 
64. Micó, R. Radiocarbon dating and Balearic prehistory: Reviewing the periodization of the prehistoric sequence. Radiocarbon 2006, 48, 421-434. [CrossRef]

65. Melis, R.T.; Depalmas, A.; Di Rita, F.; Montis, F.; Vacchi, M. Mid to late Holocene environmental changes along the coast of western Sardinia (Mediterranean Sea). Glob. Planet. Chang. 2017, 155, 29-41. [CrossRef]

66. Melis, R.T.; Di Rita, F.; French, C.; Marriner, N.; Montis, F.; Serreli, G.; Sulas, F.; Vacchi, M. 8000 years of coastal changes on a western Mediterranean island: A multiproxy approach from the Posada plain of Sardinia. Mar. Geol. 2018, 403, 93-108. [CrossRef]

67. Beffa, G.; Pedrotta, T.; Colombaroli, D.; Henne, P.D.; van Leeuwen, J.F.N.; Süsstrunk, P.; Kalterieder, P.; Adolf, C.; Vogel, H.; Pasta, S.; et al. Vegetation and fire history of coastal north-eastern Sardinia (Itlay) under changing Holocene climates and land use. Veget. Hist. Archaeobot. 2016, 25, 271-289. [CrossRef]

68. Van Geel, B. Non-Pollen Palynomorphs. In Tracking Environmental Change Using Lake Sediments; Smol, J.P., Birks, H.J.B., Last, W.M., Bradley, R.S., Alverson, K., Eds.; Developments in Paleoenvironmental Research; Springer: Dordrecht, The Netherlands, 2001; pp. 99-119.

69. Reille, M. Origine de la végétation actuelle de la Corse sud-orientale; analyse pollinique de cinq marais côtiers. Pollen Spores 1984, $1,43-60$.

70. Currás, A.; Ghilardi, M.; Peche-Quilichini, K.; Fagel, N.; Vacchi, M.; Delanghe, D.; Dussouillez, P.; Vella, C.; Bontempi, J.M.; Ottaviani, J.C. Reconstructing past landscapes of the Eastern plain of Corsica (NW Mediterranean) during the last $6000 \mathrm{yr}$ based on macrofaunal, sedimentological and palynological analyses. Geoarchaeology of the Mediterranean Islands. J. Archaeol. Sci. Rep. 2017, 12, 755-769.

71. Revelles, J.; Ghilardi, M.; Vacchi, M.; Rossi, V.; Currás, A.; López-Bultò, O.; Brkojewitsch, G. Coastal landscape evolution of Corsica: Palaeoenvironments, vegetation history and human impacts since the Early Neolithic period. Quat. Sci. Rev. 2019, 225, 105993. [CrossRef]

72. Lugliè, C. Your path through the sea ... The emergence of Neolithic in Sardinia and Corsica. Quat. Int. 2018, 470, 285-300. [CrossRef]

73. Ghilardi, M. Lagunes et Marais Littoraux de Corse. De la Préhistoire à nos Jours. Collection Orma: La Corse archéologie, ARAC Edi-tion. Available online: https:/ / www.araceditions.com/ (accessed on 14 May 2021).

74. Vacchi, M.; Ghilardi, M.; Melis, R.T.; Spada, G.; Giaime, M.; Marriner, N.; Lorscheid, T.; Morhange, C.; Burjachs, F.; Rovere, A. New relative sea-level insights into the isostatic history of the Western Mediterranean. Quat. Sci. Rev. 2018, 201, 396-408. [CrossRef]

75. Buurman, P.; Pape, T.; Muggler, R.C.C. Laser grain-size determination in soil genetic studies: Practical problems. Soil Sci. 1996, 162, 211-218. [CrossRef]

76. Buurman, P.; de Boer, K.; Pape, T. Laser Diffraction grain-size characteristics of Andisols in perhumid Costa Rica: The aggregate size of allophane. Geoderma 1997, 78, 71-91. [CrossRef]

77. Dean, W.E. Determination of carbonate and organic matter in calcareous sediments and sedimentary rocks by loss on ignition: Comparison with other methods. J. Sediment. Petrol. 1974, 44, 242-248.

78. Avramidis, P.; Panagiotaras, D.; Papoulis, D.; Kontopoulos, N. Sedimentological and geochemical characterization of Holocene sediments, from Alikes lagoon, Zakynthos island, Western Greece. Bull. Geol. Soc. Greece 2010, 43, 558-567. [CrossRef]

79. Emmanouilidis, A.; Katrantsiotis, C.; Norström, E.; Risberg, J.; Kylander, M.; Ali Sheik, T.; Iliopoulos, G.; Avramidis, P. Middle to late Holocene palaeoenvironmental study of Gialova Lagoon, SW Peloponnese, Greece. Quat. Int. 2018, 476, 46-62. [CrossRef]

80. Croudace, I.W.; Rindby, A.; Rothwell, R.G. ITRAX: Description and evaluation of a new multi-function X-ray core scanner. Geol. Soc. Spec. Publ. 2006, 267, 51-63. [CrossRef]

81. Brisset, E.; Guiter, F.; Miramont, C.; Delhon, C.; Arnaud, F.; Disnar, J.R.; Poulenard, J.; Anthony, E.; Meunier, J.D.; Wilhelm, B.; et al. Approche multidisciplinaire d'une séquence lacustre holocène dans les alpes du sud au Lac Petit (Mercantour, alt. $2200 \mathrm{~m}$, France): Histoire d'un géosystème degrade. Quaternaire 2012, 23, 309-319.

82. Thompson, R.; Battarbee, R.W.; O'Sullivan, P.E.; Oldfield, F. Magnetic susceptibility of lake sediments. Limnol. Oceanogr. 1975, 20, 687-698. [CrossRef]

83. Evans, M.E.; Heller, F. Environmental Magnetism-Principles and Applications of Enviromagnetics; Academic Press: Amsterdam, The Netherlands, 2003; p. 299.

84. Ghilardi, M.; Kunesch, S.; Styllas, M.; Fouache, E. Reconstruction of Mid-Holocene sedimentary environments in the central part of the Thessaloniki Plain (Greece), based on microfaunal identification, magnetic susceptibility and grain-size analyses. Geomorphology 2008, 97, 617-630. [CrossRef]

85. Ghilardi, M.; Delanghe, D.; Demory, F.; Leandri, F.; Pêche-Quilichini, K.; Vacchi, M.; Vella, M.A.; Rossi, V.; Robresco, S. Enregistrements d'événements extrêmes et évolution des paysages dans les basses vallées fluviales du Taravo et du Sagone (Corse occidentale, France) au cours de l'âge du Bronze moyen à final: Une perspective géoarchéologique. Géomorphologie, Relief Process. Environ. 2017, 23, 15-35. [CrossRef]

86. Maher, B.A. Magnetic properties of modern soils and loessic paleosols: Implications for paleoclimate. Palaeogeogr. Palaeoclim. Palaeoecol. 1998, 137, 25-54. [CrossRef]

87. Stuiver, M.; Polach, H.A. Discussion reporting of ${ }^{14} \mathrm{C}$ Data. Radiocarbon 1977, 19, 355-363. [CrossRef]

88. Goiran, J.P.; Morhange, C. Geoarcheology of ancient mediterranean harbours: Issues and case studies; Lyon: Association des amis de la Bibliothèque Salomon Reinach. Topoi Orient 2003, 11, 647-669. 
89. Stuiver, M.; Pearson, G.W.; Braziunas, T. Radiocarbon Age calibration of marine samples back to 9000 cal. YR BP. Radiocarbon 1986, 28, 980-1021. [CrossRef]

90. Heaton, T.; Köhler, P.; Butzin, M.; Bard, E.; Reimer, R.; Austin, W.; Bronk-Ramsey, C.; Grootes, P.M.; Hughen, K.A.; Kromer, B.; et al. Marine20-The Marine Radiocarbon Age Calibration Curve (0-55,000 cal BP). Radiocarbon 2020, 62, 779-820. [CrossRef]

91. Siani, G.; Paterne, M.; Arnold, M.; Bard, E.; Métivier, B.; Tisnerat, N.; Bassinot, F. Radiocarbon reservoir ages in the Mediterranean Sea and Black Sea. Radiocarbon 2000, 42, 271-280. [CrossRef]

92. Vella, M.A.; Andrieu-Ponel, V.; Cesari, J.; Leandri, F.; Pêche-Quilichini, K.; Reille, M.; Poher, Y.; Demory, F.; Delanghe, D.; Ghilardi, M.; et al. Early Impact of Agropastoral Activities and Climate on the Littoral Landscape of Corsica since Mid-Holocene. PLoS ONE 2019, 14, e0226358. [CrossRef]

93. Rius, D.; Vannière, B.; Galop, D.; Richard, H. Holocene fire regime changes from multiple-site sedimentary charcoal analyses in the Lourdes basin (Pyrenees, France). Quat. Sci. Rev. 2011, 30, 1696-1709. [CrossRef]

94. Leys, B.A.; Commerford, J.L.; McLauchlan, K.K. Reconstructing grassland fire history using sedimentary charcoal: Considering count, size and shape. PLoS ONE 2017, 12, e0176445. [CrossRef] [PubMed]

95. Lestienne, M.; Jouffroy-Bapicot, I.; Leyssenne, D.; Sabatier, P.; Debret, M.; Albertini, P.J.; Colombaroli, D.; Didier, J.; Hély, C.; Vannière, B. Fires and Human Activities as Key Factors in the High Diversity of Corsican Vegetation. Holocene 2020, 30, $244-257$. [CrossRef]

96. Vannière, B.; Galop, D.; Rendu, C.; Davasse, B. Feux et pratiques agro-pastorales dans les Pyrénées orientales: Le case de la montagne d'Enveitg (Cerdagne, Pyrénées orientales, France). Sud-Ouest Eur. 2001, 11, $29-42$.

97. Ghilardi, M.; Istria, D.; Currás, A.; Vacchi, M.; Contreras, D.; Vella, C.; Dussouillez, P.; Crest, Y.; Colleu, M.; Guiter, F.; et al. Reconstructing the landscape evolution and the human occupation of the Lower Sagone River (Western Corsica, France) from the Bronze Age to the Medieval period. Geoarchaeology of the Mediterranean Islands. J. Archaeol. Sci. Rep. 2017, 12, 741-754.

98. D'Anna, A.; Guendon, J.L.; Pinet, L.; Tramoni, P. Espaces, territoires et mégalithes: Le plateau de Cauria (Sartène, Corse-du-Sud) au Néolithique et à l'âge du Bronze. In Impacts interculturels au Néolithique moyen: Du terroir au Territoire: Sociétés et espaces; Duhamel, P., Ed.; Colloque Interrégional sur le Néolithique (Dijon, octobre 2001), Revue Archéologique de l'Est: Dijon, France, 2006; (Suppl. 25), pp. 191-213.

99. D'Anna, A. Les statues-menhirs de Corse: Chronologie et contextes, l'exemple de Cauria. Doc. D'archéologie Méridionale 2011, 34, 21-36. [CrossRef]

100. Guilaine, J.; Leandri, F. Menhirs et stèles de Corse. Une hypothèse chronologique. L'Anthropologie 2016, 120, 107-124. [CrossRef]

101. D'Anna, A.; Guendon, J.L.; Pinet, L.; Tramoni, P. Le plateau de Cauria à l'âge du Bronze: De la lecture évènementielle à l'approche pluridisciplinaire anthropologique. In Un Siècle de Construction du Discours Scientifique en Préhistoire; Société Préhistorique Française: Paris, France, 2007; pp. 331-346.

102. Cesari, J.; Istria, D.; Leandri, F. Nouvelles découvertes de statues-menhirs du groupe de Sagone à Sant' Appianu (Vico, Corsedu-Sud). In Six Millénaires en Centre Ouest Corse: Sevi, Sorru, Cruzzini, Cinarca: Archéologie, Histoire, Architecture ET Toponymie; Patrimoine d'une île: Ajaccio, France, 2016; Volume 5, pp. 13-23.

103. Bellotti, P.; Caputo, C.; Davoli, L.; Evangelista, S.; Garzanti, E.; Pugliese, F.; Valeri, P. Morpho-sedimentary characteristics and Holocene evolution of the emergent part of the Ombrone River delta (southern Tuscany). Geomorphology 2004, 61, 71-90. [CrossRef]

104. Bini, M.; Brückner, H.; Chelli, A.; Da Prato, S.; Gervasini, L. Palaeogeographies of the Magra Valley coastal plain to constrain the location of the Roman harbour of Luna (NW Italy). Palaeogeogr. Palaeoclimatol. Palaeoecol. 2012, 337, 37-51. [CrossRef]

105. Bini, M.; Baroni, C.; Ribolini, A. Geoarchaeology as a tool for reconstructing the evolution of the Apuo-Versilian plain (NW Italy). Geogr. Fis. Din. E Quat. 2013, 36, 215-224.

106. Reille, M. New pollen-analytical researches in Corsica: The problem of Quercus ilex L. and Erica arborea L., the origin of Pinus halepensis Miller forests. New Phytol. 1992, 122, 359-378. [CrossRef] [PubMed]

107. Fontanilles-Laurelli, F. Vestiges historiques du Fium'Orbu. Rev. d'Etudes Corses 1961, 4, 5-21.

108. Cesari, J.; Ottaviani, J.C. Inventaire des Documents Pouvant Servir à la Localisation des Etablissements Romains de Corse; Rapport d'étude, Université de Nice: Nice, France, 1971; p. 355.

109. Mayewski, P.A.; Rohling, E.E.; Stager, J.C.; Karlen, W.; Maasch, K.A.; Meeker, L.D.; Meyerson, E.A.; Gasse, F.; Van Kreveld, S.; Holmgren, K.; et al. Holocene climate variability. Quat. Res. 2004, 62, 243-255. [CrossRef]

110. Bond, G.W.; Broecker, W.; Johnsen, S.; McManus, J.; Labeyrie, L.; Jouzel, J.; Bonani, G. Correlations between climate records from North-Atlantic sediments and Greenland ice. Nature 1993, 365, 143-147. [CrossRef]

111. Bond, G.W.; Showers, M.; Cheseby, R.; Lotti, P.; Almasi, P.; de Menocal, P.; Priore, P.; Cullen, H.; Hajdas, I.; Bonani, G. A pervasive Millennial-Scale Cycle in North Atlantic Holocene and Glacial Climates. Science 1997, 278, 1257-1266. [CrossRef]

112. Tainter, J.A. The Collapse of Complex. Societies; Cambridge University Press: Cambridge, UK, 1990; p. 266.

113. McAnany, P.; Norman Yoffee, N. (Eds.) Questioning Collapse. Human Resilience, Ecological Vulnerability and the Aftermath of the Empire; Cambridge University Press: Cambridge, UK, 2010; p. 392.

114. Weninger, B.; Alram-Stern, E.; Bauer, E.; Clare, L.; Danzeglocke, U.; Jöris, O.; Kubatzki, C.; Rollefson, G.; Todorova, H.; Van Andel, T. Climate Forcing Due to the 8200 Cal yr BP Event Observed at Early Neolithic Sites in the Eastern Mediterranean. Quat. Res. 2006, 66, 401-420. [CrossRef] 
115. Hassan, F.A. Nile Floods and Political Disorder in Early Egypt. In Third Millennium BC: Abrupt Climate Change and the Old World Collapse; Dalfes, H.N., Kukula, G.H., Weiss, H., Eds.; Springer: Berlin, Germany, 1997; pp. 1-23.

116. Weiss, H. Global megadrought, societal collapse and resilience at 4.2-3.9 ka BP across the Mediterranean and west Asia. PAGES Mag. 2016, 24, 62-63. [CrossRef]

117. Cline, E.H. 1077 BC: The Year Civilization Collapsed; Princeton University Press: Princeton, NJ, USA, $2014 ;$ p. 264.

118. Drake, B.L. The influence of climatic change on the Late Bronze Age collapse and the Greek Dark Ages. J. Archaeol. Sci. 2012, 39, 1862-1870. [CrossRef]

119. Berger, J.F.; Brochier, J.L.; Vital, J.; Delhon, C.; Thiebault, S. Nouveau regard sur la dynamique des paysages et l'occupation humaine à l'Âge du bronze en moyenne vallée du Rhône. In Environnements et Cultures à l'âge du Bronze en Europe occidentale; Mordant, C., Richard, H., Magny, M., Eds.; Comité des travaux historiques et scientifiques (CTHS): Paris, France, 2007; Volume 21, pp. 260-283.

120. Galop, D.; Carozza, L.; Marembert, F.; Bal, M.C. Activités agropastorales et climat durant l'Âge du Bronze dans les Pyrénées: L'état de la question à la lumière des données environnementales et archéologiques. In Environnements et Cultures à l'âge du Bronze en Europe Occidentale; Mordant, C., Richard, H., Magny, M., Eds.; Comité des travaux historiques et scientifiques (CTHS): Paris, France, 2007; Volume 21, pp. 107-119.

121. Peche Quilichini, K. Chronologie, productions matérielles et dynamiques socio-culturelles: Le point sur le séquençage de l'âge du Bronze en Corse. In 13e Rencontres du Musée Départemental de l'Alta Rocca; Publications du musée de l'Alta Rocca: Levie, France, 2013; pp. 33-77. 